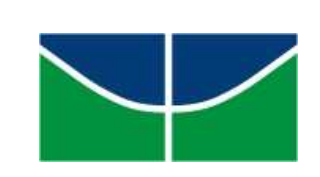

Universidade de Brasília - UnB

Faculdade de Economia, Administração, Contabilidade e Ciência da Informação e Documentação - FACE Programa de Pós-Graduação Em Administração - PPGA Curso de Especialização em Gestão Universitária

JOELDER ALVES DA SILVA

LOGÍSTICA DE ARMAZENAGEM INTERMEDIÁRIA NO SETOR PÚBLICO: ESTUDO DE UMA SECRETARIA DA UNIVERSIDADE DE BRASÍLIA

Brasília - DF 
JOELDER ALVES DA SILVA

\section{LOGÍSTICA DE ARMAZENAGEM INTERMEDIÁRIA NO SETOR PÚBLICO: ESTUDO DE UMA SECRETARIA DA UNIVERSIDADE DE BRASÍLIA}

Monografia apresentada ao Departamento de administração da Faculdade de Economia, Administração, Contabilidade e Ciência da Informação e Documentação (FACE), da Universidade de Brasília, como requisito à obtenção do grau de Especialista em Gestão Universitária.

Professor Orientador: Evaldo Cesar Cavalcante Rodrigues.

Professores Avaliadores: - Aldery Silveira Júnior. (Mestre em Administração- Departamento de Administração/FACE).

- Dra Martha Maria Veras Oliveira Cavalcante Rodrigues. (Doutora em Engenharia da Produção Faculdade de Tecnologia - FT).

\section{Brasília - DF}


A todos que de certa forma ajudaram a tornar esse meu sonho realidade. 


\section{AGRADECIMENTOS}

A Deus, por todas as graças alcançadas.

À minha família, pela educação, amor e carinho.

À Lili, minha futura esposa, pela paciência e compreensão que sempre tiveras comigo.

Ao professor Evaldo Cesar Cavalcante Rodrigues, por ter me conduzido com total atenção em todas as etapas desse trabalho. 


\section{RESUMO}

A gestão de recursos materiais na administração pública propiciou a avaliação do impacto da logística de armazenagem intermediária de uma unidade ou setor, que visa atender suas necessidades e de suas subunidades, para atender as necessidades dos clientes finais, e como poderia ser sua forma de gestão. Tem como objetivos específicos conhecer o tempo efetivo do pedido e os setores de armazenagem, identificar o fluxo da cadeia logística interna, acompanhar os procedimentos da logística reversa e verificar se o modelo logístico está atendendo às necessidades, diagnosticando os problemas ocorrentes durante o exercício. $\mathrm{O}$ almoxarifado intermediário exerce um papel importante no processo logístico, pois ao guardar certas quantidades de recursos materiais, proporciona um rápido atendimento às suas necessidades e às das subunidades de modo a não interromper as atividades devido a eventuais falhas de fornecimento por parte da central. A pesquisa foi realizada em um órgão público da administração indireta, a Fundação Universidade de Brasília, sediada no Distrito Federal e a coleta de dados ocorreu por meio de entrevistas semi-estruturadas em grupo. Participaram da pesquisa, funcionários terceirizados e servidores do quadro permanente da instituição, integrantes do corpo operacional/gerencial do almoxarifado central, intermediário, localizado na SAA (Secretaria de Administração Acadêmica) e dos postos avançados, subunidades vinculadas administrativamente a essa Secretaria. Os dados obtidos foram reunidos em quadros com o objetivo de facilitar a análise de forma isolada e agrupada, possibilitando as comparações e relações entre elas, que corroboraram para melhor visibilidade da real importância que uma armazenagem intermediária exerce dentro de uma cadeia logística interna e como os seus aspectos de gestão influenciam na eficiência das atividades. Verifica-se que a armazenagem intermediária exerce o importante papel de suprir as lacunas existentes no processo logístico institucional e que não é viável as subunidades realizarem seus pedidos junto ao almoxarifado Central. Tal estudo contribui ainda, para uma discussão sobre a necessidade de se implementar uma logística de armazenagem intermediária, tanto nos órgãos públicos quanto em qualquer outra organização que apresente tal estruturação, e o quanto essa metodologia pode vir a influenciar as políticas de administração da produção, materiais e logística.

Palavras-chave: cadeia logística, armazenagem, intermediária. 


\section{LISTA DE FIGURAS}

Figura 1 - Representação Gráfica da Logística Empresarial ...................................... 12

Figura 2 - Organograma da Secretaria de Administração Acadêmica .......................... 15

Figura 3 - Fluxo básico de compra ...................................................................... 23

Figura 4 - Canais de distribuição ........................................................................... 28

Figura 5 - Almoxarifado Central ........................................................................ 46

Figura 6 - Almoxarifado Central .......................................................................... 46

Figura 7 - Almoxarifado Intermediário .............................................................. 46

Figura 8 - Almoxarifado Intermediário ............................................................ 46

Figura 9 - Posto avançado da FACE …............................................................. 46

Figura 10 - Posto avançado do IH .......................................................................... 46

Quadro 1 - Tempo de Atendimento do Pedido ........................................................... 37

Quadro 2 - Atendimento do Pedido ...................................................................... 38

Quadro 3 - Controle/acompanhamento do pedido .................................................... 38

Quadro 4 - Pedidos Emergenciais ........................................................................... 39

Quadro 5 - Devolução de pedido ............................................................................ 39

Quadro 1 - Controle físico dos materiais .................................................................. 40

Quadro 2 - Níveis de controle ............................................................................... 40

Quadro 3 - parâmetro de ressuprimento ....................................................................... 41

Quadro 4 - Levantamento das necessidades ......................................................... 41

Quadro 5 - variação de consumo ......................................................................... 42

Quadro 6 - Tempo de estocagem ...................................................................... 42

Quadro 1 - Classificação dos itens ......................................................................... 43

Quadro 2 - Acomodação do material ......................................................................... 43

Quadro 3 - Variação de estoque ............................................................................. 44

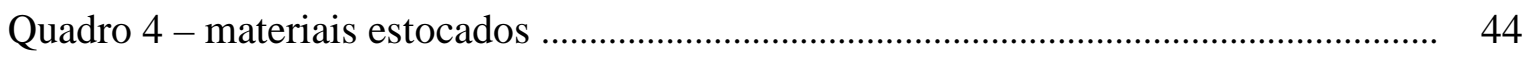

Quadro 5 - Tratamento dos itens ........................................................................ 45 
Quadro 6 - Material inútil

Quadro 1 - Espaço de armazenagem .................................................................... 47

Quadro 2 - Adaptações das instalações físicas ......................................................... 47

Quadro 3 - Espaços horizontais e verticais ............................................................ 48

Quadro 4 - Equipamentos de armazenagem ............................................................ 48

Quadro 5 - Melhorias para armazenagem .............................................................. 49

Quadro 1 - Meios de transporte ....................................................................... 49

Quadro 2 - Equipamentos para movimentação interna ............................................ 50

Quadro 3 - Rotas diárias/semanais .................................................................... 50

Quadro 4 - Retorno de material ….................................................................. 51

Quadro 1 - Sistema de informação utilizado ............................................................. 52

Quadro 2 - Disponibilização dos dados ............................................................... 52

Quadro 3 - Integração compras/setor consumo ..................................................... 53

Quadro 4 - Estoque virtual e físico .................................................................. 53

Quadro 1 - Qualificação dos profissionais ............................................................ 54

Quadro 2 - Equipamentos para proteção ………...................................................... 54

Quadro 3 - Distribuição dos funcionários .............................................................. 55

Quadro 4 - Treinamento/capacitação .................................................................... 55 


\section{SUMÁRIO}

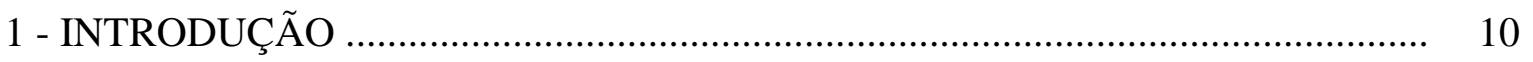

1.1 - Caracterização do ambiente ................................................................. 11

1.1.1 - Universidade de Brasília - UnB .................................................. 13

1.1.2 - Secretaria de Administração Acadêmica - SAA .............................. 14

1.1.3 - Armazenagem intermediária ....................................................... 15

1.2 - Definição do Problema de Pesquisa ........................................................ 16

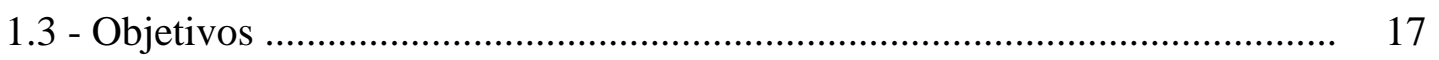

1.3.1 - Objetivo Geral .................................................................... 17

1.3.2 - Objetivo Específico ................................................................ 17

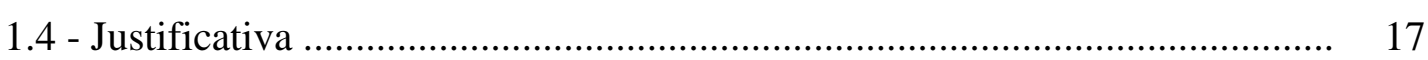

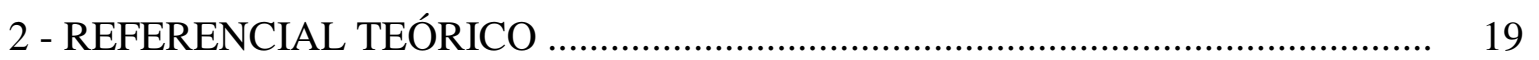

2.1 - Administração de materiais ........................................................................... 19

2.2 - Gestão de Estoques ............................................................................. 21

2.3 - Gestão de Compras ............................................................................... 22

2.4 - Compras no Setor Público .................................................................... 24

2.5 - Logística ...................................................................................... 26

2.5.1- Logística de Suprimentos e Armazenagem ..................................... 28

2.5.2- Logística de Distribuição .................................................................... 29

2.6- Localização ................................................................................................ $\quad 30$

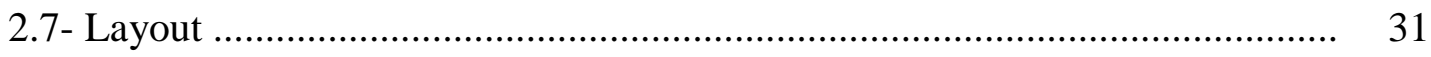

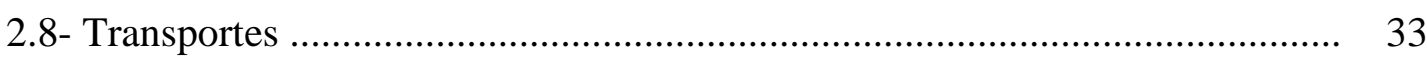

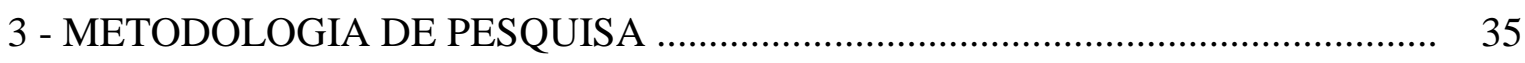

3.1- Tipo de Pesquisa ................................................................................. 35

3.2- Amostra e participantes da pesquisa ........................................................... 35

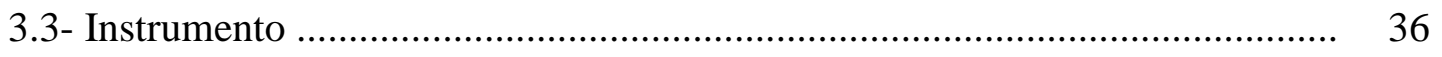

3.4- Procedimentos da coleta de dados .............................................................. 36

4 - ANÁLISE DOS DADOS ....................................................................... 37 
4.1- Variável "Pedido" ................................................................................... 37

4.2- Variável "Estocagem" ................................................................................ 39

4.3- Variável "Itens em estoque" ..................................................................... 42

4.4- Variável "Ambiente de armazenagem" ....................................................... 45

4.5- Variável "Transporte" ..................................................................................... 49

4.6- Variável "Informação Logística” .............................................................. 51

4.7- Variável "Pessoal" .................................................................................. 53

5 - CONCLUSÕES E RECOMENDAÇÕES …................................................... 56

5.1- Conclusão sobre as variáveis .................................................................... 56

5.2- Recomendações ...................................................................................... 61

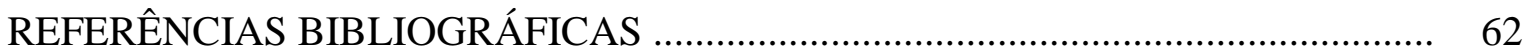

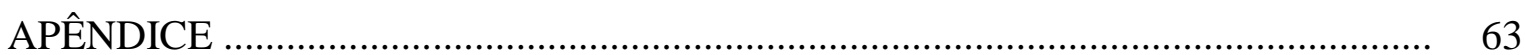




\section{Introdução}

A logística, nos dias atuais, é tratada como um campo de atuação e pode ser item fundamental para gerar competitividade na empresa. Pode ser considerada como um fator determinante no sucesso ou no fracasso dessas organizações, devido à função de responder pela movimentação de materiais, no ambiente interno e externo da organização, desde a aquisição da matéria-prima até a entrega do produto final ao cliente.

É permitido afirmar que a logística empresarial é responsável por todos os fluxos de materiais da organização, devendo agir de forma estratégica na tomada de decisões, melhorando seus processos de forma a atender melhor os clientes mantendo um estreito relacionamento com os fornecedores, devendo ser planejada, executada e controlada para que efetivamente atinja bons resultados. As funções da logística são divididas em três áreas operacionais principais: suprimento (matéria-prima), manufatura (operações de transformações em produtos) e distribuição (entrega do produto acabado). A raiz da logística empresarial começa no planejamento, baseado na oferta e demanda dos produtos e serviços oferecidos, passando para a aquisição dos insumos, produção de bens ou prestação do serviço e distribuição ao cliente, gerando informações em cada uma das etapas decorridas. A tecnologia de informação tem sido largamente utilizada como ferramenta para um melhor desempenho da logística empresarial, as informações fluem de forma rápida e é possível trabalhar muito estreitamente com fornecedores, clientes e parceiros, podendo atender às demandas mais rapidamente, diminuindo os custos e atendendo de forma mais efetiva as necessidades dos consumidores. As organizações procuraram ter um desempenho efetivo na sua logística, gerindo custos de forma que o negócio seja viável, rentável e sustentável, bem como, permita agregar valor percebido ao cliente, buscando ganhar competitividade e gerar diferenciais em relação aos concorrentes.

Através de uma correta gestão das atividades de armazenagem, manuseio, controle e transportes dos materiais, a logística empresarial consegue fazer valer o seu objetivo, que é o de fornecer ao "cliente" bens e serviços que satisfaçam suas necessidades na quantidade, localização e tempo, que são considerados por ele como apropriados. Busca, portanto, atingir um nível desejado de serviço ao cliente de forma a criar valor, quanto ao tempo e lugar, ao menor custo possível.

Não muito longe disso encontram-se as instituições públicas que, como o próprio nome já diz, consiste em prestar serviços a população e seus usuários (cliente interno e 
externo) de forma eficiente. No entanto o setor público apresenta alguns problemas com relação a tais níveis de serviço, como por exemplo, o de não conseguir enxergar o funcionário como um cliente e também disponibilizar a ele todas as condições para o trabalho. Dentro desse objetivo, de buscar a plena satisfação, surge a necessidade de se avaliar o efetivo gerenciamento da cadeia logística e dos considerados setores de suporte para armazenagem (controle de estoque e almoxarifado), como áreas de apoio úteis com foco no tripé "estoque, localização e transportes", para o desenvolvimento das atividades voltadas ao atendimento do cliente.

Os elementos do composto logístico, que são: transporte, localização e estoque, com foco nas temáticas de controle de estoque, local de armazenagem e transportes para deslocar materiais, são igualmente, essenciais para uma boa gestão logística, pois, dificilmente é possível produzir ou garantir uma eficácia na entrega ao cliente sem dar foco nos elementos citados, apesar de, alguns estudiosos da área defender, por exemplo, que o ideal seria ter estoque próximo de "zero".

Portanto, analisa-se aqui a gestão de estoques de materiais nos ambientes de armazenagens da administração pública, bem como, as operações de logística de distribuição interna realizadas para garantir um eficiente atendimento das necessidades.

\section{1 - Caracterização do ambiente}

Ao caracterizar o ambiente teórico de pesquisa, a Figura 1 classifica em partes específicas a logística empresarial, com enfoque na administração, que apropria as três áreas: administração de materiais (responsável por disponibilizar os insumos); administração da produção (todas as etapas de transformação dos insumos em produtos acabados); e administração de marketing ou mercadológica (gerencia os canais de distribuição do produto da fábrica até o cliente final). O presente trabalho está focado na interseção existente entre a logística de suprimentos e de produção, que na referida Figura 1, se apresenta como uma área de "Planejamento e Controle de Estoque". A denominação aplicada aqui foi de "Logística de Armazenagem", por se tratar de uma empresa pública para serviços de ensino, pesquisa e extensão, que apresenta como principais atividades na citada área as ações de: armazenagem, compras, movimentação interna dos estoques, controle de estoque e distribuição interna de materiais estocados para consumo dos setores da Universidade de Brasília. 


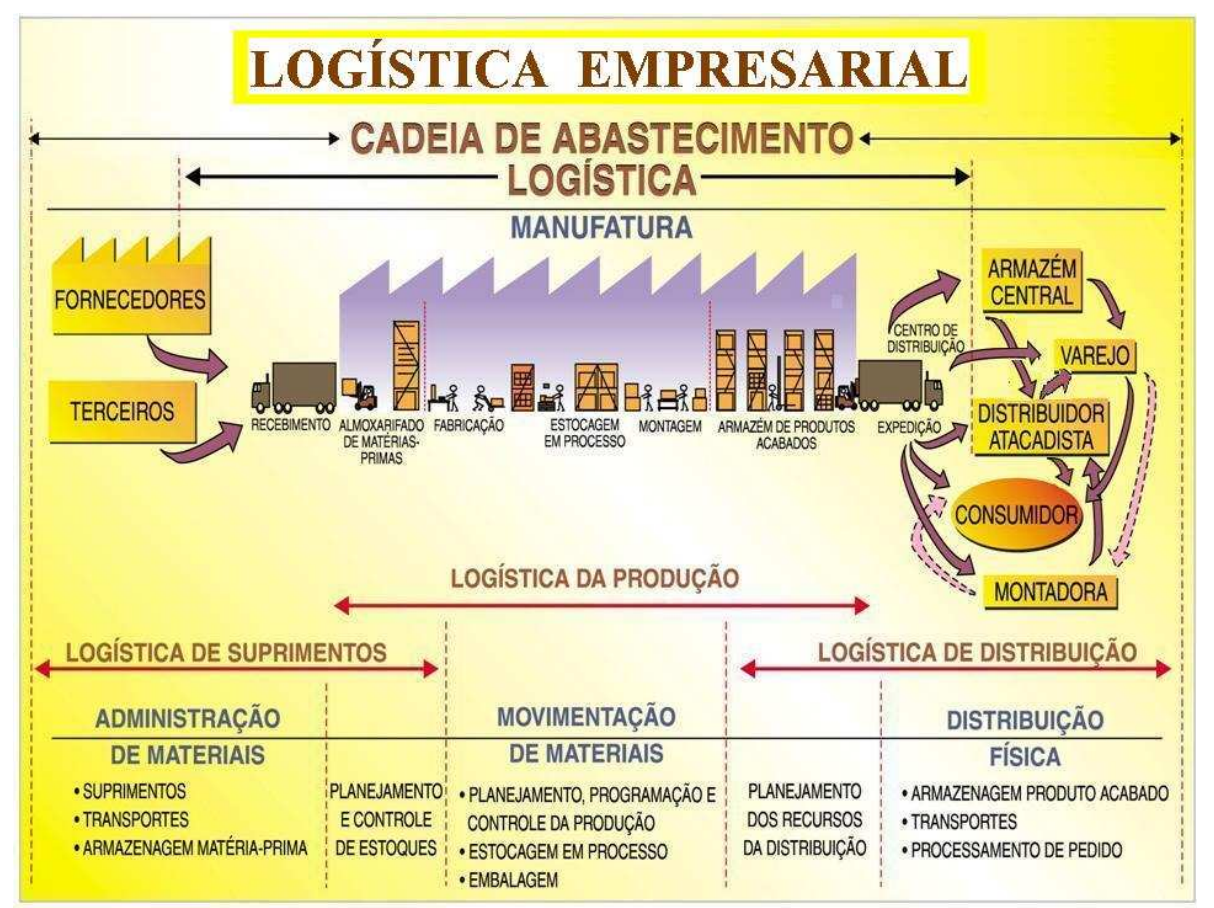

Figura 1 - Representação Gráfica da Logística Empresarial Fonte: Modificada de Ballou (2001); Slack, N. et al. (2008); Pozo (2002)

No campo de estudo prático, para tal estudo foi escolhida uma instituição pública federal, mas precisamente, a Fundação Universidade de Brasília - FUB. A doutrina moderna vem distinguindo dois tipos de fundações públicas, uma com personalidade jurídica de direito público e outra com personalidade jurídica de direito privado. Nesse sentido será dada ênfase nas de direito público por ser o campo de aplicação da pesquisa.

As fundações públicas de direito público são criadas por lei, sendo espécies de autarquias, aplicando-lhes todo o regime jurídico a que se submetem os entes autárquicos, portanto, equiparando-se às autarquias. Tais Fundações têm seu funcionamento custeado pelos recursos do governo e, dessa forma, se sujeitam à fiscalização estatal do respectivo ente federado que as criou, com receita e pessoas provenientes dos recursos do orçamento da União. Por outro lado, a autarquia, como define o Decreto-Lei n²00/67, além do patrimônio possuem também receita própria para executar atividades típicas da Administração Pública, cujas quais, requeiram gestão administrativa e financeira descentralizada.

As Fundações possuem autonomia administrativa e patrimônio próprio; executam atividades essencialmente públicas no âmbito social; submissão dos funcionários da fundação pública ao teto remuneratório do funcionalismo público, nos termos do artigo $37^{\circ}$, inciso XI da Constituição Federal; sujeição ao controle da administração direta a que estiver subordinada. 
As fundações públicas de direito público estão vinculadas também à impenhorabilidade e imprescritibilidade, que disciplina o pagamento através de ordem cronológica de precatórios judiciários e impossibilidade de usucapião de seus bens; sujeição dos atos de sua administração à ação popular e ao mandado de segurança; controle financeiro e orçamentário pelo Tribunal de Contas; sujeição ao procedimento licitatório; funcionários sujeitos a concurso público; estabilidade e demissão regulada; regime previdenciário dos servidores; acumulação de cargos e improbidade administrativa.

\subsection{1- Universidade de Brasília - UnB}

A Fundação Universidade de Brasília foi instituída pela Lei n.3.398, de 15 de dezembro de 1961, com a finalidade de criar e manter a Universidade de Brasília (UnB), instituição de ensino superior de pesquisa e estudo em todos os setores do saber e divulgação científica, técnica e cultural.

A Universidade de Brasília - UnB tem como objetivo cultivar o saber em todos os campos do conhecimento puro e aplicado, ministrar ensino de grau superior, formando profissionais e especialistas, realizar pesquisas e, por meio da promoção de atividades comunitárias e de extensão, estender o ensino e a pesquisa a toda a comunidade (Guia do calouro $2 \%$ 2009).

A UnB funciona com uma unidade orgânica, constituída de institutos, faculdades, núcleos temáticos e culturais e órgãos complementares, que dão prioridade ao estudo dos problemas relacionados ao desenvolvimento econômico, social, político e cultural do país. Tem como missão institucional produzir, aplicar, preservar e difundir idéias e conhecimentos, pesquisar, propor soluções e abrir caminhos para a sociedade, atuando como um centro dinâmico de progresso e desenvolvimento regional, nacional e internacional, comprometido com a formação profissional de alta qualificação de cidadãos éticos, socialmente responsáveis e com visão à frente do seu tempo.

As atividades de ensino, pesquisa e extensão da UnB são desenvolvidas em espaços distintos: o Campus Darcy Ribeiro, que se localiza no Plano Piloto, o Campus de Planaltina, o Campus de Ceilândia, a fazenda Água Limpa, o Centro Olímpico e o Hospital Universitário, o Campus do gama.

A estrutura organizacional da Universidade é integrada pelos Colegiados Superiores (CONSUNI, CEPE, CAD e Conselho Comunitário) e pela Reitoria (Gabinete do Reitor e do 
Vice-Reitor, Decanatos, Órgãos Complementares, Procuradoria Jurídica, Prefeitura, Auditoria, Centros, Secretarias e Assessorias).

$\mathrm{Na}$ área acadêmica a estrutura é integrada por 25 Institutos e Faculdades, Centros e Núcleos. A sua arquitetura foi aprovada na década de 70 e atualmente não atende às atuais necessidades da instituição, apesar dos novos prédios construídos recentemente.

Apresenta um almoxarifado Central, que tem por função receber todo material adquirido, de acordo com o Decreto Lei 200/67, Lei n ${ }^{\circ}$ 4320/6.4, Instrução Normativa SEDAP n $n^{\circ}$ 205/88 e normas complementares em vigor, observando se o material confere com as especificações solicitadas (marca, modelo), de forma a armazená-las e posteriormente distribuí-los aos departamentos solicitantes.

\subsection{2- Secretaria de Administração Acadêmica - SAA.}

A Secretaria de Administração Acadêmica - SAA - é um órgão de execução diretamente vinculado ao gabinete da Vice-Reitoria - VRT, conforme Ato da Reitoria $n^{\circ}$ 74/2005 que aprova a sua nova estrutura organizacional, e caracteriza-se como uma unidade responsável pelo registro, acompanhamento, controle da vida acadêmica de todo o corpo discente (Graduação e Pós-graduação) da Universidade de Brasília e dos seus Campi, o que representa cerca de 35.000 (trinta e cinco mil) alunos.

A SAA possui atualmente um quadro de 85 (oitenta e cinco) colaboradores, divido entre servidores, terceirizados e estagiários, distribuídos na sede da Secretaria, localizada no Sub-Solo do prédio da Reitoria, e nos 12 (doze) Postos Avançados (subunidades administrativas descentralizadas localizadas no espaço físico das unidades acadêmicas) sendo que 3 (três) destes estão situados nos campi das cidades de Ceilândia, Gama e Planaltina DF. Todos respondem pelos serviços de registros de matrículas, trancamentos, apropriações de menções finais, emissões de declarações e históricos escolares, desligamentos, registro de diplomas, tanto da UnB quanto das IES particulares (Instituição de Ensino Superior). Também prestam atendimento aos professores e servidores de outros órgãos da Universidade de Brasília dando suporte técnico aos sistemas acadêmicos. A figura 1.1 apresenta um gráfico da estrutura hierárquica e organizacional do SAA, chamado de organograma. 


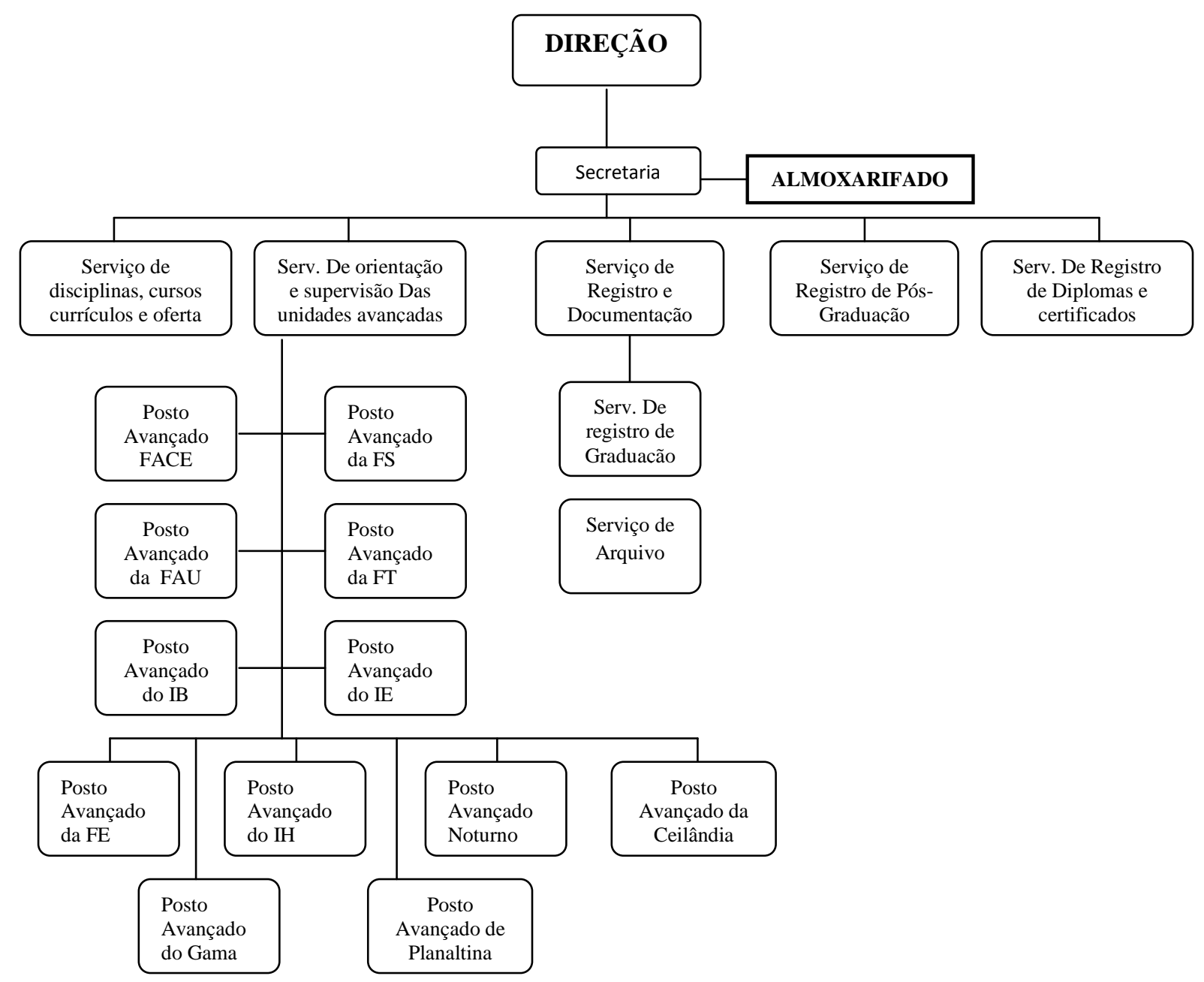

Figura 2 - Organograma da Secretaria de Administração Acadêmica Fonte: Ato da Reitoria n ${ }^{\circ} 74 / 2005$

Por ser a unidade administrativa com maior contato direto junto à comunidade acadêmica da UnB e por possuir uma estrutura de atendimento bastante descentralizada, foi necessária a criação de um almoxarifado dentro da estrutura da SAA com o objetivo de estocar pequenas quantidades de materiais destinados aos seus trabalhos e proporcionar um rápido atendimento, principalmente, às demandas das subunidades.

\subsection{3- Armazenagem intermediária}

Geralmente por serem afastadas e não possuírem contato direto com o almoxarifado central, as subunidades, no caso os postos avançados, necessitam do apoio logístico da Secretaria quanto ao fornecimento dos materiais necessários às suas atividades. Dessa forma, o almoxarifado situado na SAA passa a ter a função de intermediar essa distribuição, se transformando na única fonte de suprimento para essas subunidades. 
Tal almoxarifado intermediário é conceituado, conforme Araújo (1985), de subalmoxarifado, que na sua visão, trata-se de uma mera agência do almoxarifado central ou moderna filial instalada dentro do próprio setor, a fim de estocar pequenas quantidades destinadas aos seus trabalhos e a atender demandas eventuais. A única atenção a ser dada com relação a esse conceito é que o almoxarifado intermediário da SAA não é subordinado hierarquicamente ao almoxarifado central da Universidade, trata-se de uma gestão própria da Secretaria.

As características principais dos sub-almoxarifados são a sua capacidade de controle do espaço físico, da segurança e do abastecimento das áreas de produção. De suma importância estratégica para o sucesso de um negócio, tem influência decisiva nos processos de planejamento da produção e no controle de fluxo de materiais. Esses estoques intermediários quando gerenciados de forma errada tornam-se um dos grandes geradores de desperdícios, obsolescência e de gargalos, vindo a ter reflexos diretos e significativos na eficiência da distribuição.

Apesar de ser uma área com maior referência nas indústrias de produção, esse estudo veio verificar como uma unidade do setor público poderia gerir um estoque intermediário de forma a atender as necessidades de materiais com entregas imediatas ou em prazos muito curtos.

\section{2 - Definição do Problema de Pesquisa}

As instituições públicas, cujo fim, consiste em prestar serviços a população e seus usuários de forma eficiente, devem também, nesse sentido, disponibilizar aos funcionários todas as condições necessárias para o trabalho fornecendo os materiais adequados para a prestação dos serviços. Dentro desse objetivo, de alimentar a produção, surge a necessidade de se avaliar o efetivo gerenciamento da cadeia logística, como os setores de gestão de estoques e almoxarifados, tidos como áreas de apoio úteis para o desenvolvimento das atividades voltadas ao atendimento do cliente.

Portanto, ao analisar os aspectos de gestão dos recursos materiais da secretaria de Administração Acadêmica, como sendo fonte de fornecimento para suas subunidades, surgiu a necessidade de responder a seguinte indagação: Como uma unidade do setor público poderia gerir um estoque intermediário de materiais de forma a atender eficientemente suas necessidades e às das subunidades? 


\section{3 - Objetivos}

\subsection{1- Objetivo Geral}

Avaliar o impacto da logística de armazenagem intermediária de uma unidade do setor público, que visa a atender suas necessidades e às das subunidades, para atender as necessidades dos clientes.

\subsection{2 - Objetivos específicos}

Pretendeu-se com os objetivos específicos:

- Conhecer o tempo efetivo do pedido e os setores de armazenagem;

- Identificar o fluxo da cadeia logística interna;

- Acompanhar os procedimentos da logística reversa;

- Verificar se o modelo logístico está atendendo às necessidades;

- Diagnosticar os problemas ocorrentes durante o exercício;

\section{4 - Justificativa}

No atual cenário competitivo empresarial é clara a importância de se otimizar os recursos, aumentar a satisfação dos clientes e obter como resultado o lucro financeiro. Porém, ao analisar o setor público verifica-se que, este, também não foge dessa perspectiva, exceto a respeito dos fins lucrativos que são atributos exclusivos das empresas. Sendo assim, para que tais órgãos proporcionem um eficiente atendimento e a plena satisfação, tanto do cliente externo (cidadão) quanto do interno (servidor), surge a necessidade de se avaliar o efetivo gerenciamento da cadeia logística como área de apoio para o desenvolvimento das atividades envolvidas nesse processo.

Nesse raciocínio os materiais são tidos como itens ou componentes que um setor utiliza nas suas operações diárias para a consecução do seu objetivo, sendo necessário, portanto, uma boa administração que os disponibilize nas quantidades adequadas e no tempo correto. E para que haja essa eficiente distribuição, justifica-se dessa forma, a existência de um almoxarifado, pois é nele que ficaram armazenados os materiais que sustentarão o funcionamento das atividades. Viana (2002) o define como o local destinado à fiel guarda e 
conservação dos materiais até o consumo final. De tal forma, esse deve possuir condições para assegurar que o material adequado, na quantidade devida, estará disponível no local certo e no tempo certo conforme a necessidade.

Ao tomar como base o campo de aplicação desse presente estudo, verifica-se que além da existência de um almoxarifado, tido como "central", a maioria das outras unidades da instituição possuem em suas dependências pequenos depósitos ou almoxarifados, onde guardam quantidades menores de recursos materiais afim de não interromper suas atividades e às de suas subunidades devido a eventuais falhas de fornecimento por parte da central.

Tais almoxarifados intermediários, conceituados conforme Araújo (1985) de subalmoxarifados, são não sua visão, meras agências dos almoxarifados centrais ou modernas filiais instaladas dentro do próprio setor, a fim de estocar pequenas quantidades destinadas aos seus trabalhos e a atender demandas eventuais. Outra característica que justifica sua existência é o rápido atendimento que proporciona, principalmente em relação às subunidades, por serem geralmente afastadas e não possuírem contato direto com o almoxarifado central.

A necessidade de se avaliar o efetivo gerenciamento da cadeia logística interna, com foco no almoxarifado da Secretaria de Administração Acadêmica - SAA surgiu pelo fato de essa ser a unidade de maior contato junto à comunidade acadêmica e por possuir uma estrutura de atendimento descentralizada realizada através de suas subunidades, os postos avançados.

Dada a importância de se possuir um estoque intermediário, obtêm-se com este estudo, uma maior visibilidade quanto aos aspectos gerenciais relativos a essa complexa cadeia logística interna de suprimento, existentes no setor público, bem como uma maior contribuição para a discussão sobre uma metodologia que possa a vir influenciar as políticas de administração dessa ciência, tanto nos órgãos públicos quanto em qualquer outra organização que apresente tal estruturação. 


\section{2 - Referencial Teórico}

\section{1 - Administração de materiais}

Primeiramente é importante buscar a definição do que vem a ser materiais no ramo da administração, para então, aprofundar os aspectos que tratam da sua gestão. Materiais são, portanto, itens ou componentes que uma empresa utiliza nas suas operações do dia-dia, na elaboração do seu produto final ou na consecução do seu objetivo social, que podem ser armazenados ou que serão consumidos imediatamente após a sua chegada. Baseado nesse conceito estão excluídos os materiais considerados permanentes, como equipamentos, móveis e veículos, e incluídos os demais produtos, como materiais de escritório, alimentos, limpeza, reagentes, conservação e reparos.

A administração de materiais tem como função disponibilizar os recursos necessários ao processo produtivo com qualidade, quantidades adequadas, no prazo certo e com o menor custo possível. Sendo que a qualidade deverá ser de modo que haja aceitação interna e externa à organização, com quantidade estreitamente suficiente para suprir as necessidades evitando a falta de materiais ou seu excesso em estoque.

Tal ciência é uma ramificação da Administração Geral que abrange a execução e gestão de tarefas que tem seu início na identificação do fornecedor, na compra do bem, em seu recebimento, transporte interno, armazenagem e em sua distribuição ao consumidor final. Corresponde, portanto, no seu todo, segundo Viana (2002), às funções de planejamento, organização, direção, coordenação e controle das operações necessárias destinadas às atividades funcionais de uma organização, visando o aumento da produtividade e rentabilidade. Para isso é necessário saber comprar, evitar consumo desnecessário e desperdícios, para não correr o risco de faltas, além de armazenar adequadamente e minimizar perdas.

A política de material de cada empresa varia conforme estão classificados os seus materiais e segundo seu ramo de atividade. Conforme Dias (2008) a classificação é essencial, pois sem ela não pode haver um controle eficiente dos estoques, e nem uma armazenagem e operacionalização correta do almoxarifado. Além dessa, existem outras técnicas que auxiliam uma boa gestão de materiais, como por exemplo, a padronização dos materiais em uso organização, que se dá pela aplicação de especificações técnicas e pela existência de um programa de classificação e catalogação de materiais. Outra política básica é o 
acompanhamento do ciclo dos materiais do qual visa preparar e programar a introdução dos materiais na organização. Com isso evita-se desperdício de recursos, paralisação da empresa pela falta do referido material, além da eliminação de estoques inutilizados e sucatas excessivas ao fim da vida útil do material. Deve-se ter especial atenção ao processo de procura e obtenção dos materiais. Atualmente com a tendência de globalização da economia as fontes fornecedoras multiplicaram-se em número, fazendo com que as equipes encarregadas destas atividades tenham uma crescente complexidade no seu trabalho.

Outra preocupação básica do administrador ou gestor de materiais é com relação ao transporte. Seja ele interno ou externo, um baixo desempenho na sua execução pode comprometer a atividade fim da organização. Deve-se estar sempre atento às modernas técnicas e equipamentos de transporte, além da evolução das relações comerciais com aquelas empresas prestadoras de serviço nesta área, ou seja, empresas terceirizadas em transporte, que sob análise de Martins e Alt (2006), podem vir a ser empregadas como uma importante maneira de economia de tempo e recursos do que se utilizado meios próprios.

De crucial importância a armazenagem de materiais também é uma preocupação constante. Embora muitos não se atentem disso, a armazenagem tem um custo além do próprio custo do estoque imobilizado, como a posse e conservação da área, conservação dos próprios materiais, custos com segurança, pessoal e outros. Assim pela padronização e pelo planejamento deve-se procurar reduzir a quantidade de material armazenado e aumentar a velocidade com que ele entra e sai desses locais. Nesse sentido é preciso estar atento às modernas técnicas e equipamentos de armazenagem e embalagem, para aumento da eficiência e redução de custos.

A administração de estoques é também uma tarefa de extrema importância, talvez uma das principais dessa ciência, da qual o administrador de materiais não deve se descuidar. Sua eficiência leva à redução de materiais armazenados, citada acima, possibilita uma previsão de consumo e aquisições, além de permitir todo o planejamento do ciclo de materiais da empresa.

Por fim, uma análise detalhada sobre toda a gestão material é uma exigência que se faz ao administrador ou ao competente da área. Não somente devido o capital financeiro empregado, mas, principalmente, pela maior rapidez e precisão no atendimento aos clientes/usuários quando se trata de órgãos públicos, ou pela vantagem competitiva que a empresa pode obter em relação aos concorrentes, no caso daquelas que objetivam o lucro financeiro. 


\section{2- Gestão de Estoques}

A administração dos estoques objetiva otimizar o investimento mantendo níveis adequados e satisfatórios de materiais capazes de atender às necessidades dos clientes. É visto como um recurso produtivo que gera valor, pois, assume um papel importantíssimo para todas as empresas que desejam obter uma vantagem competitiva em relação aos seus concorrentes.

A gestão de estoques se constitui por uma série de ações que permitem ao administrador verificar se os estoques estão sendo bem utilizados, bem localizados em relação aos setores que deles se utilizam, e se estão bem manuseados e controlados.

Apesar de ser clara a sua importância, há críticos que contestam a necessidade de manutenção de estoques, por considerarem desnecessários e onerosos. Conforme Ballou (2006) o custo de manutenção pode representar cerca de 20 a $40 \%$ do seu valor por ano e que embora os custos sejam altos os sistemas operacionais podem não estar projetados para reagir instantaneamente às solicitações dos clientes, justificando assim a necessidade de se manter algum nível de estoque, apesar do ideal ser algo próximo de zero.

$\mathrm{Na}$ tentativa constante de reduzir os estoques e consequentemente os custos, sejam de matérias-primas de produtos em processos ou de produtos acabados/consumo, desenvolveu-se novas técnicas administrativas, como as de origem japonesa: Just in time e Kanban. Just in time, na definição de Martins e ALt (2006) é um método em que os fornecedores entregam os suprimentos somente à medida que eles vão sendo necessários na produção ou consumo, eliminando, de tal forma, desperdícios e reduzindo custos. Já a técnica Kanban (etiqueta ou cartão) utiliza-se de um cartão de sinalização ou luzes cuja função é controlar os fluxos de produção ou transportes em uma indústria. Permite agilizar a entrega na hora da produção.

Portanto a política de estoques deve-se ater à máxima eficiência ao menor custo e buscar o equilíbrio entre estoque e consumo, que poderá ser obtido, na ótica de Viana (2002), através de algumas regras e critérios que ajudam no controle:

- Determinar o que deve permanecer em estoque;

- Determinar os níveis de estoque para cada material (máximo, mínimo e segurança) bem como a necessidade de consumo para um período pré-determinado;

- Acionar o departamento de compras para acelerar a aquisição de materiais com variação de consumo;

- Realizar o acompanhamento permanente e o planejamento das atividades de gestão;

- Identificar e retirar do estoque os itens danificados, obsoletos e inservíveis; 
Outra função importantíssima, que faz parte das ações de controle de estoque, é a de planejamento. O objetivo do planejamento é não deixar faltar material necessário ao consumo/produção, evitando um alto impacto na mobilização dos recursos financeiros. Segundo Bowersox e Closs (2001) os procedimentos e parâmetros essenciais para o planejamento de estoque se concentram em três aspectos: Determinação do ponto de ressuprimento, ou seja, quando se deve pedir; determinação do lote de compra, quanto pedir; e definição dos procedimentos de controle. Para evitar a falta de estoque, ocasionada por uma demanda que excede as previsões, faz-se necessário a inserção do estoque de segurança, que também, além de ser planejado, deve seguir alguns parâmetros, como a avaliação sobre a possibilidade da falta de estoque e o potencial de demanda durante os possíveis períodos de falta.

Analisar detalhadamente os estoques é uma exigência que se faz a todo administrador de material. Não só pelo volume de capital envolvido, mas, pela busca da satisfação do usuário/fornecedor e pela vantagem competitiva. Diversas são as ferramentas que auxiliam na busca de tais objetivos (giro de estoque, cobertura, análise ABC, acurácia) cabe, por tanto, ao gestor competente, juntamente com os métodos de avaliação (custo médio, método PEPS, e UEPS), fazer a escolha correta a ser executada para uma análise mais precisa.

\section{3- Gestão de Compras}

As compras são realizadas tendo como objetivo suprir as necessidades dos materiais nas empresas de acordo com as quantidades e qualidades especificadas no planejamento. $\mathrm{Na}$ visão de Dias (2008) tal atividade não se restringe somente à aquisição, mas compreende também responsabilidades quanto ao recebimento e o armazenamento do que foi comprado. Entre as atividades associadas incluem-se segundo Ballou (2006):

- Seleção e avaliação do desempenho de fornecedores;

- Negociar contratos, comparar os preços, qualidade e serviços;

- Pesquisar bens e serviços;

- Programar as compras e estabelecer os termos das vendas;

- Avaliar o valor e mensurar a qualidade recebida;

- Prever possíveis alterações de preços/serviços; 
Viana (2002) propõe uma espécie de fluxograma que representa bem os procedimentos e as várias etapas referentes ao processo de compra.

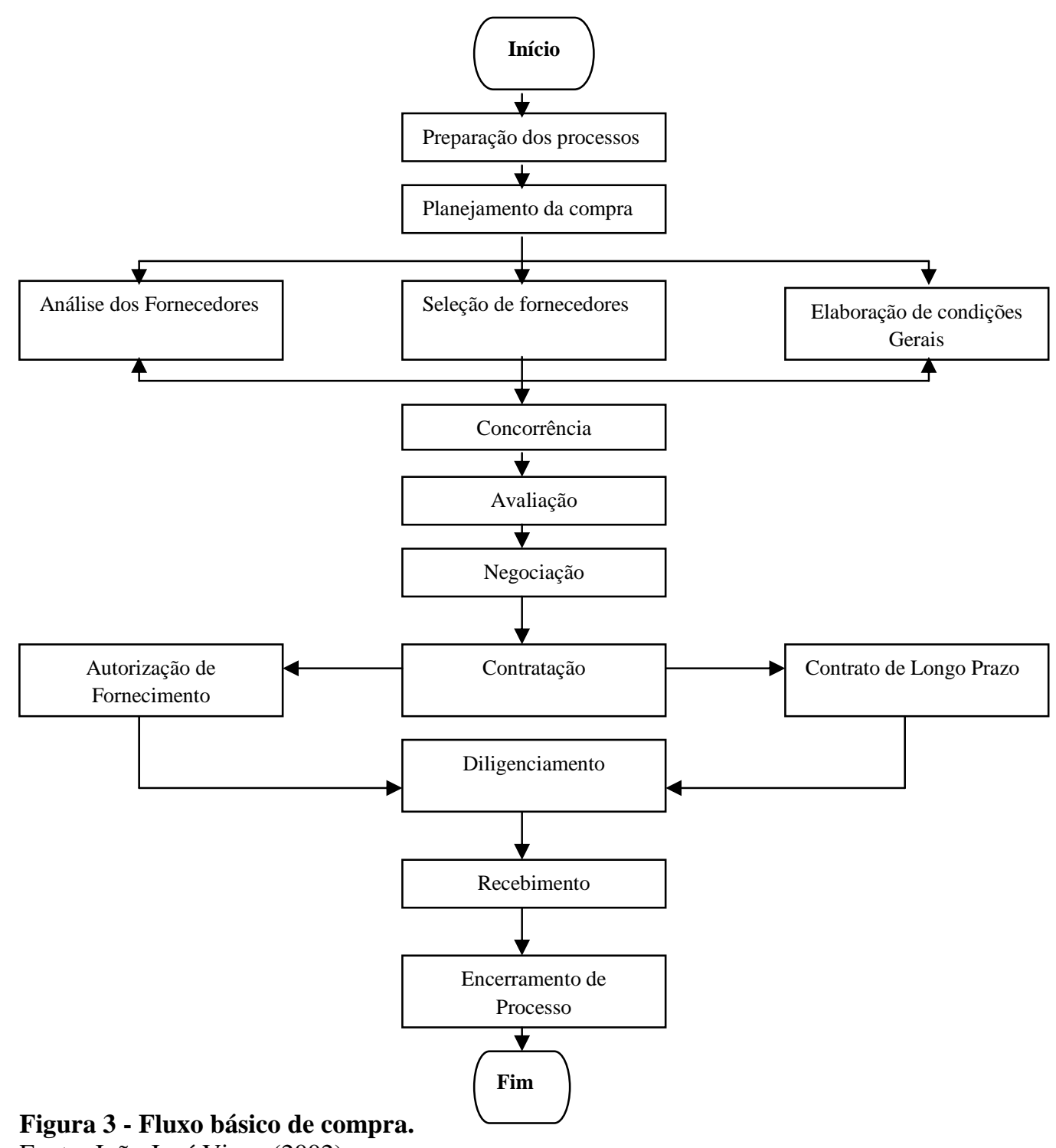

Fonte: João José Viana (2002).

Denominada também como atividade de suprimentos, compras tem por finalidade suprir as necessidades da empresa mediante a aquisição de materiais, a partir das demandas dos usuários, sem desprezar a necessidade de identificar no mercado as melhores condições comerciais e técnicas dos produtos e dos fornecedores (VIANA 2002).

Para Martins e Alt (2000) as operações de suprimentos passaram a ter um significado mais estratégico, pois, a mesma requer planejamento, devido à necessidade de decidir o quê, quando e quanto comprar, principalmente se considerar o volume de recursos financeiros da organização de maneira a racionalizar os gastos. Sendo assim eles afirmam que os objetivos do setor de compras devem estar alinhados aos objetivos estratégicos da organização, 
buscando sempre, de tal forma, satisfazer ao cliente interno e externo com o melhor atendimento.

A área de compras também deve se atentar com os níveis de estoque da empresa. Quando os níveis estão altos minimizam os problemas relativos às faltas de produtos, porém, acarretam em um grande custo com capital, espaço físico e com pessoal do almoxarifado. Por outro lado trabalhar com níveis baixos é altamente arriscado, qualquer imprevisto poderá causar uma ruptura de estoque e prejudicar todo processo, acarretando em reclamações por parte dos clientes.

Pensando em contornar tais problemas, Viana (2002) analisa que os parâmetros de ressuprimento devem estar ajustados, em função do consumo, do prazo de reposição e do valor de cada material. Viana (2002) argumenta que se faz necessário manter um estoque mínimo, de reserva ou de segurança, capaz de suportar variações que podem ocorrer durante o tempo de ressuprimento. Também analisa que deve haver o planejamento de um estoque máximo, ou seja, determinar a quantidade máxima de um item em estoque, informando o ponto de ressuprimento de forma a não onerar os custos com materiais excedentes.

Portanto compras é uma área que deve interagir com todas as outras áreas da organização, recebendo e processando as informações necessárias para a boa gestão, como também, trabalhando essas informações a níveis gerenciais a fim de alimentar outros setores com informações úteis na tomada de decisão.

\section{4- Compras no Setor Público}

Em órgãos públicos, as normas relativas à função compras são estabelecidas em dispositivos legais, cuja complexidade varia conforme o valor financeiro envolvido no processo. Tal processo de aquisição executado pelos órgãos públicos, denominado de licitação, tem como objetivo atender às necessidades organizacionais, inclusive relativos à compra de materiais destinados a execução de suas atividades.

Licitação é definida, conforme Mello (2003), como o procedimento administrativo no qual a administração pública, proporcionando igual oportunidade a todos interessados, seleciona a proposta mais vantajosa para a realização de um contrato de interesse público, cujo objeto pode ser: o de alienar, adquirir ou locar bens, realizar obras ou serviços e outorgar concessões e permissões. No serviço público em geral (administração direta, indireta, autárquica e fundacional) toda e qualquer aquisição deve ser regulamentada pela lei 8666/93 e 
seguir aos princípios da igualdade, publicidade, probidade administrativa, procedimento formal sigilo na apresentação das propostas, vinculação ao instrumento convocatório (edital), julgamento objetivo e adjudicação compulsória ao vencedor.

O processo de licitatório se inicia com a emissão de requisição de compras, cuja qual, depende do modelo de gestão de estoques adotado, podendo ser gerada de forma manual ou automática, para só então dar início à montagem do processo. Depois de tomadas essas providências preliminares, tal processo é remetido à autoridade competente para aprovação da despesa e reserva do recurso necessário para efetuar a aquisição. A próxima fase trata da escolha da modalidade de licitação, que terá como parâmetros os valores envolvidos especificados conforme art. 23 da lei 8666/93:

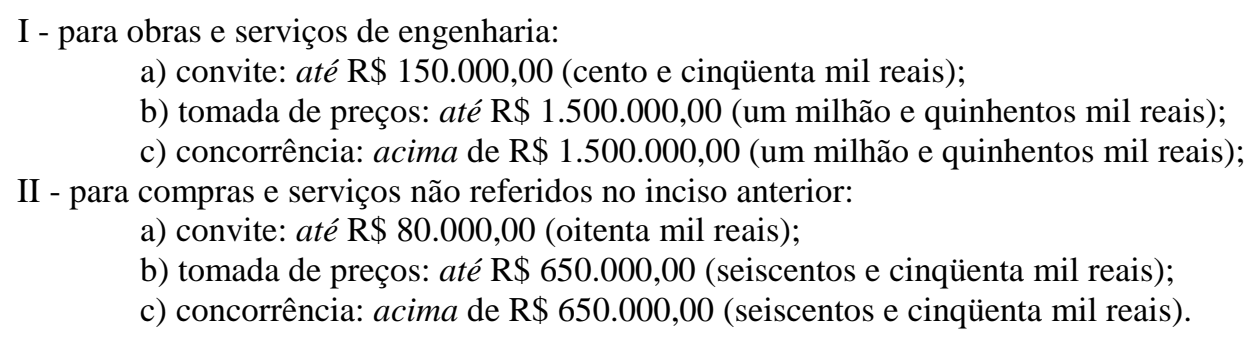

Posteriormente virá a convocação dos fornecedores, recebimento das propostas, julgamento e adjudicação. Adjudicação é definida, conforme Albuquerque (2007), como a atribuição do objeto da licitação ao vencedor do certame.

Apesar de ser obrigatório fazer a licitação, em alguns casos, os órgãos públicos podem comprar diretamente de um fornecedor sem a necessidade de realizar tal processo, conforme explicita o art. 37, Inciso XXI da Constituição Federal:

\begin{abstract}
XXI - ressalvados os casos especificados na legislação, as obras, serviços, compras e alienações serão contratados mediante processo de licitação pública que assegure igualdade de condições a todos os concorrentes, com cláusulas que estabeleçam obrigações de pagamento, mantidas as condições efetivas da proposta, nos termos da lei, o qual somente permitirá as exigências de qualificação técnica e econômica indispensáveis à garantia do cumprimento das obrigações.
\end{abstract}

Tal legislação, a lei 8666/93 que regulamentou esse Inciso, explicita em seu conteúdo que a licitação pode ser inexigível ou dispensável conforme o caso, sendo que, aquela ocorre quando não é possível realizar uma licitação, pois não existe a competição, ou seja, não existe concorrência no mercado, quando só uma empresa pode oferecer determinado produto, em caso de notória especialização e na contratação de profissional do meio artístico. Já a dispensável acontece quando o governo até poderia organizar uma licitação, mas, por conveniência e oportunidade ele não o faz. O exemplo mais claro da dispensa são as compras 
cujos valores não ultrapassam os $\mathrm{R} \$ 8.000,00$ (oito mil) reais ou $\mathrm{R} \$ 15.000,00$ (quinze mil) para obras e serviços.

Atualmente os órgãos públicos utilizam muito das ferramentas eletrônicas para a dispensa de licitação por limite de valor e acabam preparando os compradores e fornecedores para a utilização massiva de ferramentas eletrônicas, como o pregão eletrônico.

O pregão eletrônico foi criado através da lei federal 10.520/2002 visando, basicamente, aumentar a quantidade de participantes e baratear o processo licitatório. $\mathrm{O}$ pregão acontece numa sala virtual, onde as propostas são apresentadas pelos concorrentes e ganha o fornecedor que pedir o menor preço pela mercadoria ou serviço. Se bem aplicada, essa ferramenta eletrônica proporciona um maior conforto quanto à apresentação das ofertas por parte do fornecedor e torna o processo mais eficiente e econômico.

Após finalizado todo o processo de julgamento das propostas e a adjudicação do objeto, realiza-se a homologação autorizando o proponente a celebrar o contrato com a entidade compradora. Emite-se então o empenho com a autorização para a entrega do material ou a prestação do serviço. No caso de compras, a lei define as hipóteses em que há a obrigatoriedade do contrato, do contrário, o empenho é considerado documento equivalente.

\section{5 - Logística}

O processo logístico afeta, praticamente, direta ou indiretamente, todas as áreas da atividade humana. Para se ter uma idéia é só imaginar como é possível comprar aqui no Brasil um tênis ou uma camisa produzido nos Estados Unidos, ou ainda um sapato produzido na China. A influência da logística no nosso dia-a-dia é de fundamental importância em diversos setores, e não como algumas pessoas costumam alegar que a logística é importante apenas nas operações industriais, diminuindo tal grau nas operações comerciais e tornando-se pouco importante na área de prestação de serviço.

Em definição, logística trata-se do conjunto de atividades que englobam o processo de planejar, executar e controlar, eficientemente, a movimentação, transporte e armazenagem dos materiais, garantindo o cumprimento dos prazos de entrega aos usuários. Para os níveis de maior complexidade operacional a logística é regida, de modo mais analítico, por atividades como: o histórico de demanda dos produtos ou serviços, histórico da frequência dos pedidos, histórico das quantidades por pedido, custos envolvidos na operação, tempo de entrega, prazos de entrega, pedido mínimo, rupturas de abastecimento, sazonalidades, políticas de 
estoque (evitando faltas ou excessos), planejamento da produção, políticas de transportes, políticas de gestão dos pedidos, análise dos modelos de canais de distribuição, entre outros. Em linhas gerais, pode-se dizer que a Logística está presente em todas as atividades de uma organização.

Contudo, sob análise de Ballou (2006) a logística não é um processo inteiro, completo como um todo, e sim faz parte do processo mais complexo: o da cadeia de suprimentos, ou mais conhecido como gerenciamento da cadeia de suprimentos. É um estudo que trata de uma gestão mais integrada com as áreas de produção, finanças e marketing. Cooperam com o marketing, por exemplo, para determinar as necessidades, desejos e a satisfação dos clientes quanto ao serviço. No caso a logística começa por aí, pela necessidade do cliente. Sem essa necessidade, não há movimento de produção e nem entrega.

Ainda sob a perspectiva de Ballou (2006), uma empresa ao se propor disponibilizar um produto não disponível anteriormente em estoque ou ainda levá-lo ao cliente no tempo certo, criará um valor para ele que antes não existia. Um negócio qualquer pode gerar quatro tipos de valor em serviços ou produtos para os clientes: o valor forma, relacionado com o produto acabado; o valor lugar e tempo, por meio do transporte para o lugar certo; e o valor posse, considerado de responsabilidade do departamento de Marketing, engenharia e finanças, é criado ao despertar o desejo de aquisição pelos clientes. Assim reforça que a satisfação das necessidades dos clientes internos e externos faz parte da missão da logística.

Em função das diversas atividades que devem ser realizadas para satisfazer as necessidades logísticas e consequentemente à dos clientes, surge a idéia de relacionamento na cadeia de suprimentos. Várias organizações já utilizam da gerência de relacionamento na estrutura dos canais. Conforme Bowersox e Closs (2001), canal de distribuição é o meio por onde se realiza a transferência de propriedade de produtos e serviços por certo período, até que se finalize o processo de comercialização, que vai desde o fornecedor, passando por agentes, firmas, distribuidores, atacadistas, varejistas, até o consumidor final. Já a gerência de relacionamento é uma expressão que trata da cooperação entre todos os participantes de um canal. Uma relação que pode proporcionar maior nível de desempenho conjunto.

A figura abaixo mostra um grupo de participantes envolvidos em um canal simples de distribuição: 


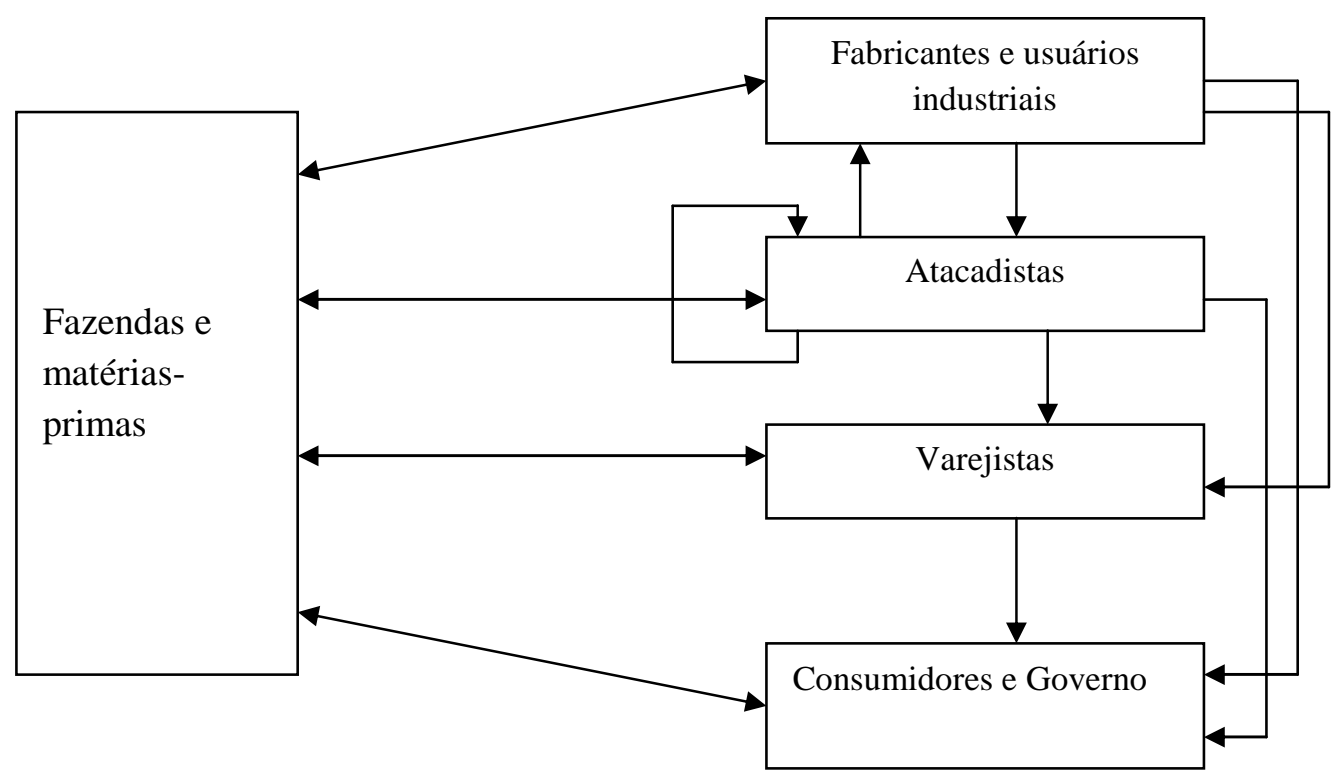

Figura 4 - canais de distribuição.

Fonte: Bowersox e Closs (2001).

Assim os canais são definidos claramente como sistemas de relacionamento entre entidades que participam do processo de compra e venda de produtos e serviços, mas, é importante analisar que nem todos os participantes de um canal têm o mesmo interesse no sucesso das relações, como por exemplo, um varejista que dispõe de seus ativos na forma de estoque e uma empresa de transporte de cargas que se limita somente à entrega dos produtos. Só através da cooperação no âmbito de todo o canal é que se pode ter as necessidades logísticas permanentes satisfeitas.

Apesar de ser fácil pensar em logística como simples gerenciamento do fluxo dos produtos, que vai desde a aquisição até o consumidor final, várias empresas já se utilizam do canal logístico reverso (devolução, por parte dos clientes, de produtos obsoletos, danificados ou para substituição - Ballou 2006-) cujo qual também precisa de total atenção, pois, em um ambiente competitivo há a necessidade de melhorar cada vez mais o nível serviço prestado após a entrega. O gerenciamento logístico surge como uma ferramenta poderosa capaz de assegurar a satisfação do cliente/usuário durante todo o processo da cadeia.

\subsection{1- Logística de Suprimentos e Armazenagem}

O termo suprimento, segundo Bowersox e Closs (2001), é utilizado para incluir todos os tipos de compras. Abrange, portanto, as atividades relacionadas com a obtenção de materiais e produtos de fornecedores externos, bem como a organização da movimentação de 
entrada desses materiais ou produtos acabados para as fábricas, montadoras ou depósitos. $\mathrm{O}$ principal objetivo é dar apoio à produção ou à revenda, conforme o caso, proporcionando compras em tempo hábil, ao menor custo total.

Ao tomar o setor de manufatura (a fábrica) como ponto de referência básica, pode-se identificar a logística de suprimentos como aquela que lida com os fluxos de materiais de fora para dentro da manufatura, incluindo matéria-prima, outros insumos e produtos acabados. Os principais componentes da logística de suprimentos na visão de Alvarenga e Novaes (2000) são:

- Obtenção do produto ou retirada da matéria-prima na sua origem e preparo da mesma para o transporte.

- Deslocamento desde o fornecedor até o local de manufatura, que corresponde ao transporte da mesma.

- Estocagem/ armazenamento dos materiais na fábrica, aguardando que os produtos sejam manufaturados.

A armazenagem, atividade importante nesse processo, tem por função ajudar no alcance da missão da organização de forma a manter um suprimento adequado e oferecer uma proteção em face da incerteza operacional e da demanda. Ela leva soluções para os problemas de estocagem de materiais que possibilitam uma melhor integração entre as cadeias de suprimento, produção e distribuição.

Suas instalações, conforme cita Viana (2002), devem proporcionar a movimentação rápida e fácil dos suprimentos, desde o recebimento até a expedição. Dias (2008) afirma que um sistema correto de armazenamento influi no aproveitamento da matéria-prima e nos meios de movimentação, evitando a rejeição de peças e redução nas perdas de material com manuseio e extravios.

\subsection{2- Logística de Distribuição}

Distribuição é uma atividade da logística responsável pelo fluxo dos materiais/produtos, desde a saída da linha de produção até a entrega do produto no destino final, estando ligada a movimentação e a transportes (VIANA 2002).

De acordo com a situação de cada organização, Viana (2002) cita que a distribuição pode ser classificada de duas formas: 
- Distribuição interna: refere-se à movimentação de matéria-prima, componentes ou peças para manutenção, do almoxarifado ao setor requisitante, para dar continuidade às atividades de produção da empresa.

- Distribuição externa: trata da entrega dos produtos ou serviços da empresa ao seu cliente consumidor final, adotando-se a denominação de distribuição física.

Bowersox e Closs (2001) definem distribuição física como a movimentação de produtos acabados para entrega aos clientes. Na distribuição física o cliente é o destino final dos canais de marketing. Há, portanto, nesse sentido, uma relação entre essas funções, pois é pelo processo de distribuição física que o tempo e o espaço do serviço ao cliente se tornam parte integrante de marketing. O setor de marketing ao pensar nos clientes, visualiza atributos, tais como a satisfação dos desejos, entrega nos prazos adequados, e o setor de logística de distribuição os viabiliza concretamente por meio do transporte adequado, armazéns e depósitos estrategicamente localizados (ALVARENGA e NOVAIS 2000).

A distribuição é vista como um dos processos mais importantes nas empresas, pois problemas como o atraso na entrega são refletidos diretamente no cliente. A partir do momento que o produto é vendido a distribuição se torna uma atividade capaz de trazer benefícios ou problemas resultantes de sua atuação. Conforme Dias (2008) sua importância também pode ser visualizada quando tratada em termos de custos. Para muitas empresas os custos de distribuição determinam a sua rentabilidade pelo fato de engolirem seus lucros. Dessa forma ele apresenta uma definição para o conceito de distribuição que abrange a utilização dos canais existentes com a finalidade de maximizar a sua contribuição para a lucratividade, equilibrando as necessidades de atendimento dos clientes com os custos incorridos.

\section{6 - Localização}

Nos estudos sobre localização dos centros de distribuição a redução nos custos de transporte e as economias de escala de produção são os principais objetos de atenção. $\mathrm{O}$ processo de localização, bem como as respectivas decisões, abrangem diversos aspectos, como a quantidade de centros de distribuição, os clientes a serem atendidos por centro, as linhas de produtos a serem armazenadas e os canais utilizados para o suprimento de materiais.

A escolha do local influencia o valor dos investimentos a serem realizados, tanto no presente quanto no futuro, e os custos de produção a serem incorridos ao longo da vida útil do 
projeto logístico. Desta forma a competitividade do empreendimento será afetada por essa decisão, tornando a situação praticamente irreversível. Sua importância decorre dos altos investimentos envolvidos e dos profundos impactos que as decisões de localização têm sobre os custos logísticos. Bowersox e Closs (2001) defendem que os custos de transporte são os mais importantes e na maioria das vezes são proporcionais ao tempo de viagem, ao peso e a distancia.

Sob a visão de Ballou (2006), ao se analisar métodos de localização é importante classificar os problemas de localização em uma quantidade limitada de categorias como: o número de instalações, horizonte de tempo e força direcionadora. Essa avaliação sobre a localização de fábricas e armazéns é uma decisão única que pode ser auxiliada por ferramentas computacionais que facilitam as tarefas e o tratamento dos dados. Sendo que tais dados a serem analisados consistem principalmente em definições de mercados, produtos, redes (abrangendo os componentes dos canais), demanda dos clientes, preço de transporte e dos custos variáveis e fixos.

O estudo sobre a localização tornou-se um fator substancial na análise do planejamento logístico e mesmo após a sua construção ou instalação é importante as empresas executarem avaliações, sejam anuais ou mensais, sobre os canais de distribuição alternativos, as alterações nos custos logísticos e a disponibilidade de novos serviços, principalmente no que diz respeito a transportes, pois o mercado não é estável e exige que as organizações sejam dinâmicas e flexíveis quanto a esse aspecto de localização.

\section{7- Layout}

Objetivando aperfeiçoar as condições de trabalho e a satisfação de todos, principalmente a do cliente, com relação a arrumação de móveis, equipamentos e materiais, não só na instalação (inicial) como também nas reestruturações e adaptações que possam ocorrer, as empresas devem se atentar ao estudo do layout. Dias (2008) o define como a integração do fluxo de materiais, de operação e de movimentação de equipamentos, e arranjo de homens e máquinas com o objetivo de conferir melhores condições de operação e maior produtividade.

Corresponde, no sentido mais amplo, à distribuição física de elementos em determinado espaço com intuito de satisfazer as necessidades dos clientes, funcionários, e fornecedores, provocando uma interação com o ambiente organizacional e um aumento da 
produtividade. A realização de seu estudo, em ambientes como armazéns e estoques, objetiva segundo Viana (2002):

- Maior e melhor utilização do espaço físico;

- Mais eficiência na movimentação dos materiais;

- Redução de custos com mão-de-obra, equipamentos e dos danos com materiais.

O planejamento desse espaço, de forma mais detalhada, deve levar em conta, por exemplo, as mercadorias que têm maior fluxo, armazenando-as próximas aos pontos de expedição, corredores e portas para facilitar o acesso e o manuseio das mercadorias e equipamentos, um espaço de armazenagem temporária próximo do local de expedição e um acostamento para veículos condizente com a quantidade de embarques e desembarques. Operações como essas visam conforme análise de Viana (2002) citada anteriormente, reduzir o desperdício de mão-de-obra em operações de transporte, evitar o esforço físico excessivo e acidentes, procurando ganhar espaço útil com a melhor disposição das máquinas e materiais, sendo esse, o espaço, um dos principais problemas apontados nos almoxarifados.

Além da interação entre o espaço físico e o fator humano o layout deve ser flexível a fim de que possa ser alterado sempre que necessário. Pois no atual contexto mundial as mudanças, sejam no aspecto político, administrativo, cultural ou financeiro são cada vez mais constantes. Nesse sentido Dias (2008) analisa algumas situações que podem provocar mudanças no layout, como o desenvolvimento ou modificação de um produto, um aumento ou redução na demanda e um ambiente de trabalho inadequado e obsoleto. Incluem-se nessas situações os ruídos, temperaturas anormais, iluminação imprópria, aspectos ergonômicos, enfim todos os fatores que podem afetar o bom andamento das atividades e o rendimento no trabalho.

Por tais razões o espaço deve ser apropriado, tanto quanto possível, em perfeita sintonia com as necessidades das pessoas e a natureza do trabalho. E para elaboração de um bom layout Cury (2005) ressalta que todas as operações indispensáveis à realização do trabalho devem receber uma análise minuciosa auxiliada por um fluxograma, pois, o foco é fazer com que os materiais cheguem ao seu destino de forma contínua, sem interrupções ou gargalos. 


\section{8- Transportes}

Transporte é a função logística responsável pela política e pela execução da movimentação e distribuição de material (consumo e matéria-prima), bem como a entrega de produtos acabados para os clientes.

Dentro das operações logísticas o transporte representa para diversas empresas o elemento mais importante e mais visível em termos de custos logísticos, sendo estes, proporcionais ao tempo e a distância da entrega. Tais gastos variam de acordo com a decisão de utilizar uma frota própria ou uma transportadora terceirizada. Portanto o objetivo é minimizar o tempo e os custos aumentando a satisfação dos clientes em relação ao desempenho da entrega.

Conforme Bowersox e closs (2001) o transporte possui duas funcionalidades principais: movimentação e armazenagem de produtos. A movimentação tem por objetivo o deslocamento dos produtos de um local de origem até um destino determinado, minimizando os custos financeiros relativos ao tempo, ambiente e às perdas, agregando de tal forma valor, aproximando os produtos cada vez mais do cliente final. O transporte também realiza a função de armazenagem temporária quando, por exemplo, o custo de descarregar e recarregar o produto for maior que a taxa diária de uso do próprio meio de transporte.

A movimentação dos produtos pode ser feita de vários modos: marítimo, rodoviário, ferroviário e aeroviário. A escolha depende do tipo de mercadoria a ser transportada, das características da carga, da pressa e, principalmente dos custos.

No Brasil, o modo de transporte mais utilizado é o rodoviário, sendo justificado, na visão de Dias (2008), pela política de investimentos na área de rodovias, implantação de indústrias automobilísticas e refinarias de petróleo e pela inacessibilidade em alguns municípios por outros meios de transporte. Outros pontos também favorecem para a escolha desse tipo de sistema como a flexibilidade em operar nos diversos tipos de estradas, movimentar pequenas cargas a curtas distancias e uma entrega consideravelmente rápida e confiável. Apesar dos pontos positivos, tal setor não está livre de problemas, e as principais dificuldades encontradas são com relação aos custos, que se compõem de taxas de licenças, impostos ao usuário, pedágios, mão de obra alta e cara, substituição e manutenção de equipamentos.

Na busca de um bom gerenciamento do transporte, a fim de obter diminuição dos custos, dois princípios fundamentais são analisados por Bowersox e Closs (2001): a economia 
de escala e a economia de distancia. A economia de escala é obtida quando toda a capacidade do veículo é utilizada, dessa forma seria possível afirmar que o custo é menor ainda, por exemplo, quando os meios forem o marítimo ou ferroviário, devido possuírem maior capacidade. Já a economia de distancia preconiza a idéia de que o custo diminui à medida que a distância aumenta, sendo vinculada também ao aumento do tamanho da carga (economia de escala). Ballou (2006) ao se referir sobre perfis de tarifas, ou preços cobrados pela prestação do serviço, também analisa que estas têm relação com volume, distancia e demanda. Sendo essa última relacionada ao limite máximo que o usuário se dispõe a pagar ao transportador.

Embora as tarifas de frete ocupem lugar de destaque na determinação do tipo de transporte o serviço em si continua sendo o principal fator determinante na hora da escolha, pois, o objetivo geral de um transporte é distribuir o produto certo, no lugar certo, no momento certo, com o nível de serviço desejado e com o menor preço possível até o cliente. 


\section{3- Metodologia de Pesquisa}

\section{1- Tipo de pesquisa}

Foi realizada uma pesquisa qualitativa através dos métodos "entrevista em profundidade" e de "observação sistemática". Qualitativa porque, segundo Acevedo e Nohara (2007), são úteis para determinar as razões ou os porquês e conhecer os fatores que afetam o comportamento humano nas organizações, bem como, o reflexo deste no desempenho das atividades de logística de armazenagem, foco deste estudo. Buscam analisar profundamente grupos ou indivíduos específicos, diferentemente das pesquisas quantitativas, que estão preocupadas com amostras coletadas de um grande número de pessoas.

Por sua vez a entrevista em profundidade caracteriza-se por uma entrevista em grupo objetivando que este revele suas atitudes, quanto aos aspectos de gestão de estoque e de distribuição dos materiais, de forma livre (ACEVEDO e NOHARA-2007). Conforme tal entrevista, essa pode variar, segundo sua estruturação, em totalmente não estruturadas ou semi-estruturadas. Optou-se por essa última, pois os pontos da discussão e o propósito da entrevista foram preestabelecidos antes da entrevista, partindo de um esquema básico e não rigoroso que permitisse adaptações, sendo, portanto, conduzida por um entrevistador qualificado, que no caso foi o próprio pesquisador.

O método da observação sistemática caracteriza-se, conforme Acevedo e Nohara (2007), pelo registro do comportamento dos investigados e pelo fato do pesquisador já ter planejado e estruturado os aspectos a serem registrados com a observação. Tal método foi utilizado, principalmente, devido o acompanhamento das rotinas diárias que o pesquisador já realiza em seu setor, objeto de estudo.

\section{2- Amostra e participantes da pesquisa}

Participaram da pesquisa, funcionários terceirizados e servidores do quadro permanente da instituição, sendo estes, integrantes do corpo operacional/gerencial da atividade meio estudada. Correspondem, de forma mais específica, aos funcionários do almoxarifado: central, intermediário (SAA) e 2 (dois) postos avançados (FACE e IH), que estão situados nas unidades foco da pesquisa. 
Tais sujeitos foram escolhidos por se tratarem, dentre outros, os que possuem maior conhecimento com relação aos aspectos de logística de armazenagem de suas respectivas unidades organizacionais.

Optou-se pelo posto avançado da FACE por este atender a maior parcela da comunidade acadêmica, o que equivale a cerca de 10 (dez) cursos. O posto do IH foi escolhido por se localizar em um ponto mais estratégico, ou seja, no prédio do Instituto Central de Ciências - ICC, local de melhor acesso e onde há o maior fluxo de pessoas.

\section{3- Instrumento}

As informações a respeito da logística de armazenagem foram coletadas por meio de uma entrevista em profundidade, de forma grupal, com a participação mínima de 2 (dois) funcionários por unidade, e semi-estruturada, conforme citado anteriormente, com um roteiro na forma de questionário. Também foram coletados dados através do método de observação, realizados de modo a investigar as atitudes e ações referentes ao planejamento, organização, controle do estoque e distribuição dos materiais, bem como as percepções, expectativas e sugestões dos funcionários em torno da logística de armazenagem.

\section{4 - Procedimentos da coleta de dados}

A pesquisa foi realizada por meio de uma entrevista em profundidade e registrada pessoalmente pelo próprio pesquisador. Foi elaborada uma solicitação de forma prévia e expressa para autorização e ciência de todos os funcionários dos setores envolvidos.

As entrevistas foram realizadas entre os dias 23 de fevereiro e 08 de março, em horário previamente marcado, de acordo com a conveniência dos entrevistados e de preferência na sua própria unidade de trabalho, de forma a proporcionar uma melhor visibilidade dos aspectos práticos da gestão de estoques. 


\section{4 - Análise dos Dados}

Nessa seção são apresentados os resultados referentes aos métodos de gestão praticados pelo almoxarifado Central, intermediário (SAA) e de Ponta (postos avançados), onde os dados obtidos foram reunidos em quadros, conforme cada variável (pedido, estocagem, itens estocados, ambiente de armazenagem, transporte, informações logísticas e pessoal) a seguir definida, com o objetivo de facilitar a análise de forma isolada e agrupada, de maneira que possibilite as comparações e relações entre elas para identificação dos impactos de uma logística de armazenagem intermediária no setor público.

\section{1 - Variável "Pedido".}

O estudo da variável "pedido" tem por objetivo analisar como vêm sendo conduzido o processo de obtenção do material, período que vai desde a emissão do pedido de compra até o momento do efetivo recebimento, englobando também os de caráter emergencial, e se são entregues conforme o planejado por cada unidade.

\subsubsection{Pergunta: tempo de Atendimento do Pedido.}

- Foi apresentada a seguinte pergunta aos entrevistados: qual o led time do pedido e é satisfatório (do momento da solicitação até a entrega)?

Quadro 1 - Tempo de Atendimento do Pedido.

\begin{tabular}{|l|l|l|l|}
\hline \multicolumn{1}{|c|}{$\begin{array}{c}\text { Almoxarifado } \\
\text { Central }\end{array}$} & \multicolumn{1}{|c|}{$\begin{array}{c}\text { Almoxarifado } \\
\text { Intermediário }\end{array}$} & $\begin{array}{l}\text { Posto Avançado da } \\
\text { FACE }\end{array}$ & Posto Avançado do IH \\
\hline $\begin{array}{l}\text { Varia de 30 a 45 dias } \\
\text { e não é satisfatório }\end{array}$ & $\begin{array}{l}04 \text { dias úteis ou mais } \\
\text { (depende do estoque) e não é } \\
\text { satisfatório }\end{array}$ & $\begin{array}{l}\text { Um dia, se possuir } \\
\text { em estoque - } \\
\text { Satisfatório. }\end{array}$ & $\begin{array}{l}\text { No mesmo dia, se possuir } \\
\text { em estoque - Satisfatório. }\end{array}$ \\
\hline
\end{tabular}

Análise do Tempo do Pedido: o tempo de entrega do fornecedor externo junto ao almoxarifado central é muito longo e pode ocasionar a falta nas demais unidades. No entanto, os prazos citados pelos demais estão condicionados à existência do material no estoque do seu fornecedor e, mesmo assim, o lead time entre o almoxarifado Central e o Intermediário não é satisfatório. 


\subsubsection{Pergunta: formato do Atendimento do Pedido.}

- Foi apresentada a seguinte pergunta aos entrevistados: os pedidos são atendidos nas devidas quantidades? Qual o percentual atendido?

Quadro 2 - Atendimento do Pedido.

\begin{tabular}{|l|l|l|lr|}
\hline \multicolumn{2}{|c|}{$\begin{array}{c}\text { Almoxarifado } \\
\text { Central }\end{array}$} & \multicolumn{1}{|c|}{$\begin{array}{c}\text { Almoxarifado } \\
\text { Intermediário }\end{array}$} & \multicolumn{1}{c|}{$\begin{array}{c}\text { Posto Avançado da } \\
\text { FACE }\end{array}$} & \multicolumn{2}{c|}{ Posto Avançado do IH } \\
\hline $\begin{array}{l}85 \% \text { dos pedidos } \\
\text { chegam nas é entregue na } \\
\text { quantidades. }\end{array}$ & $\begin{array}{l}80 \% \text { é } \\
\text { quantidade solicitada. }\end{array}$ & $\begin{array}{l}\text { Cerca 35\% do que é } \\
\text { solicitado é entregue nas } \\
\text { quantidades. }\end{array}$ & $\begin{array}{l}\text { Cerca de 90\% das } \\
\text { solicitações são atendidas } \\
\text { nas quantidades. }\end{array}$ \\
\hline
\end{tabular}

Análise do Atendimento do Pedido: em geral os pedidos não são entregues conforme o planejado por cada unidade. O problema inicia com o fornecedor externo e se dissemina aos demais afetando a gestão do estoque. A situação do posto Avançado da FACE é a mais crítica, pois há uma distinção muito grande entre os demais, podendo prejudicar de forma mais grave, o atendimento ao usuário final.

4.1.3 Pergunta: gestão do Controle/ acompanhamento do pedido.

- Foi apresentada a seguinte pergunta aos entrevistados: como é visualizado o controle/ acompanhamento de cada pedido?

Quadro 3 - Controle/acompanhamento do pedido.

\begin{tabular}{|l|l|l|c|}
\hline \multicolumn{1}{|c|}{ Almoxarifado Central } & \multicolumn{1}{|c|}{$\begin{array}{c}\text { Almoxarifado } \\
\text { Intermediário }\end{array}$} & $\begin{array}{c}\text { Posto Avançado da } \\
\text { FACE }\end{array}$ & $\begin{array}{c}\text { Posto Avançado } \\
\text { do IH }\end{array}$ \\
\hline $\begin{array}{l}\text { Por telefone junto ao setor de compras. } \\
\text { Integração no SIMAR está suspensa. }\end{array}$ & $\begin{array}{l}\text { Acompanha apenas } \\
\text { por telefone. }\end{array}$ & $\begin{array}{l}\text { Faz apenas a cobrança do } \\
\text { material por telefone. }\end{array}$ & $\begin{array}{l}\text { Apenas } \\
\text { telefone. }\end{array}$ \\
\hline
\end{tabular}

Análise do controle/ acompanhamento do pedido: não há controle/ acompanhamento informatizado sobre os pedidos. Todas as unidades realizam o acompanhamento por telefone o que pode causar conflito de informações e erros nas previsões. A causa do almoxarifado Central não possuir tal integração com compras parece estar junto ao administrador do SIMAR, pois ela existe, mas não está em funcionamento.

\subsubsection{Pergunta: critério para pedidos Emergenciais.}

- Foi apresentada a seguinte pergunta aos entrevistados: qual o critério para atender pedidos emergenciais? 
Quadro 4 - Pedidos Emergenciais.

\begin{tabular}{|c|c|c|c|}
\hline Almoxarifado Central & $\begin{array}{l}\text { Almoxarifado } \\
\text { Intermediário }\end{array}$ & $\begin{array}{c}\text { Posto Avançado da } \\
\text { FACE }\end{array}$ & $\begin{array}{c}\text { Posto Avançado do } \\
\text { IH }\end{array}$ \\
\hline $\begin{array}{lcr}\text { Realizado } & \text { pelo setor } & \text { de } \\
\text { Compras. } & \text { Prazos } & \text { e } \\
\text { quantidades } & \text { previstos } & \text { na } \\
\text { licitação } & (25 \% & \text { para } \\
\text { acréscimos } & & \text { ou } \\
\text { supressões). } & & \end{array}$ & $\begin{array}{l}\text { Processar no SIMAR e } \\
\text { retirar pessoalmente no } \\
\text { Almoxarifado Central, } \\
\text { ou aguardar a rota de } \\
\text { entrega. }\end{array}$ & $\begin{array}{l}\text { Realizado por telefone. } \mathrm{O} \\
\text { material é separado no } \\
\text { escaninho e entregue até o } \\
\text { dia seguinte. }\end{array}$ & $\begin{array}{l}\text { Realizado por telefone } \\
\text { e a entrega é imediata, } \\
\text { no mesmo dia. }\end{array}$ \\
\hline
\end{tabular}

Análise dos pedidos emergenciais: os pedidos emergenciais solicitados pelo almoxarifado central seguem normas previstas na legislação sobre licitação. Essa unidade não diferencia os pedidos emergenciais dos demais, o solicitante, no caso, deve resgatar o material no Almoxarifado Central conforme sua emergência. Quanto aos pedidos dos postos avançados, junto ao Intermediário, o critério continua o mesmo dos pedidos normais, ou seja, por telefone.

\subsubsection{Pergunta: devolução de um pedido.}

- Foi apresentada a seguinte pergunta aos entrevistados: quais são os motivos para devolução de um pedido?

Quadro 5 - Devolução de pedido.

\begin{tabular}{|c|c|c|c|}
\hline Almoxarifado Central & $\begin{array}{l}\text { Almoxarifado } \\
\text { Intermediário }\end{array}$ & $\begin{array}{c}\text { Posto Avançado da } \\
\text { FACE }\end{array}$ & $\begin{array}{c}\text { Posto Avançado do } \\
\text { IH }\end{array}$ \\
\hline $\begin{array}{l}\text { Por defeito. Não há } \\
\text { entrega indevida. }\end{array}$ & Por defeito. & $\begin{array}{l}\text { Não ocorrem casos de } \\
\text { devolução. }\end{array}$ & Apenas por defeito. \\
\hline
\end{tabular}

Análise sobre a devolução de um pedido: as devoluções dos materiais ocorrem apenas por defeito e são encaminhados até o ponto de origem (do posto para o Almoxarifado Intermediário e deste para o "Central”). Pelo fato do almoxarifado Central não receber, de seu fornecedor, pedidos com defeitos, entende-se que esses, podem ser provenientes de ações internas inadequadas por parte de seus respectivos gestores e usuários ou má qualidade dos materiais. Dentre as unidades em estudo apenas não há históricos de devoluções de pedidos do posto avançado da FACE.

\section{2 - Variável "Estocagem"}

A variável "estocagem" tem por finalidade identificar os aspectos de gerenciamento dos estoques e os meios e técnicas de controle utilizadas para manter o equilíbrio com o 
consumo, bem como os parâmetros e níveis de ressuprimento capazes de atender as necessidades das diversas unidades em estudo.

\subsubsection{Pergunta: controle físico dos materiais.}

- Foi apresentada a seguinte pergunta aos entrevistados: como é realizado o controle físico (entrada e saída) dos materiais?

Quadro 1 - Controle físico dos materiais.

\begin{tabular}{|l|l|l|l|}
\hline Almoxarifado Central & \multicolumn{1}{|c|}{$\begin{array}{c}\text { Almoxarifado } \\
\text { Intermediário }\end{array}$} & $\begin{array}{l}\text { Posto Avançado da } \\
\text { FACE }\end{array}$ & Posto Avançado do IH \\
\hline $\begin{array}{l}\text { Todo material que entra e } \\
\text { sai é lançado no SIMAR. } \\
\begin{array}{l}\text { Inventário diário e e há método ou sistema } \\
\text { auditoria a cada } 3 \text { meses. }\end{array}\end{array}$ & $\begin{array}{l}\text { Não é realizado. } \\
\text { controle. Apenas } \\
\text { confere a entrega. Não há } \\
\text { inventário. }\end{array}$ & $\begin{array}{l}\text { Não é realizado controle } \\
\text { físico. Apenas confere a } \\
\text { entrega. }\end{array}$ \\
\hline
\end{tabular}

Análise do controle físico dos materiais: dentre as unidades em estudo, apenas no almoxarifado Central é executado um controle mais preciso e adequado, e somente o posto da FACE não realiza qualquer tipo controle, nem mesmo confere se a quantidade entregue está correta. Também não existe um sistema que auxilie na gestão dos estoques do intermediário e nos postos.

\subsubsection{Pergunta: níveis de controle de estoque.}

- Foi apresentada a seguinte pergunta aos entrevistados: quais os níveis de controle de estoque existente para os materiais (estoque mínimo, máximo e de segurança)?

Quadro 2 - Níveis de controle.

\begin{tabular}{|c|c|c|c|}
\hline $\begin{array}{c}\text { Almoxarifado } \\
\text { Central }\end{array}$ & Almoxarifado Intermediário & ado da FACE & $\begin{array}{c}\text { Posto Avançado do } \\
\text { IH }\end{array}$ \\
\hline $\begin{array}{lr}\text { É } & \text { gerenciado } \\
\text { apenas } & \text { um } \\
\text { estoque mínimo. }\end{array}$ & $\begin{array}{l}\text { Não há determinação de níveis } \\
\text { mínimos ou máximos. Apenas } \\
\text { acompanhamento visual. }\end{array}$ & $\begin{array}{l}\text { Há níveis mínimos para } \\
\text { alguns materiais, mas, sem } \\
\text { definição de quantidade. }\end{array}$ & $\begin{array}{l}\text { O estoque mínimo é } \\
\text { apenas para o consumo } \\
\text { da semana. }\end{array}$ \\
\hline
\end{tabular}

Análise dos níveis de controle: apesar de ser uma unidade que realiza um importante papel nessa cadeia, o almoxarifado intermediário é o único que não programa um estoque de segurança com objetivo de suportar variações de consumo de seus usuários, mesmo não sendo de uma maneira muito adequada como a dos postos.

4.2.3 Pergunta: parâmetro de ressuprimento utilizado. 
- Foi apresentada a seguinte pergunta aos entrevistados: que parâmetro para o ressuprimento é utilizado?

Quadro 3 - parâmetro de ressuprimento.

\begin{tabular}{|c|c|c|c|}
\hline Almoxarifado Central & $\begin{array}{l}\text { Almoxarifado } \\
\text { Intermediário }\end{array}$ & $\begin{array}{c}\text { Posto Avançado da } \\
\text { FACE }\end{array}$ & $\begin{array}{c}\text { Posto Avançado do } \\
\text { IH }\end{array}$ \\
\hline $\begin{array}{l}\text { O ponto ocorre quando o } \\
\text { estoque mínimo é } \\
\text { atingido. Baseia-se no } \\
\text { consumo anterior } \\
\text { acrescido de } 15 \% \text {. }\end{array}$ & $\begin{array}{l}\text { Toda a semana é realizado } \\
\text { um pedido. }\end{array}$ & $\begin{array}{l}\text { solicita com } \\
\text { antecedência mínima de } \\
2 \text { dias da ruptura do } \\
\text { estoque. }\end{array}$ & $\begin{array}{l}1 \text { dia antes de acabar o } \\
\text { material em estoque. }\end{array}$ \\
\hline
\end{tabular}

Análise do parâmetro de ressuprimento: cada unidade possui um parâmetro diferente correspondente ao seu consumo, onde, apenas o almoxarifado Central se baseia no estoque de segurança como ponto de ressuprimento e possui um lote de compras definido, ainda que sem o devido levantamento das necessidades. Já a política utilizada pelos postos avançados e o almoxarifado intermediário, baseada no consumo diário/semanal, incorre no risco da haver uma possível falta de materiais.

4.2.4 Pergunta: levantamento das necessidades dos setores.

- Foi apresentada a seguinte pergunta aos entrevistados: como é levantada a necessidade de cada setor?

Quadro 4 - Levantamento das necessidades.

\begin{tabular}{|l|l|l|l|}
\hline Almoxarifado Central & \multicolumn{1}{|c|}{$\begin{array}{c}\text { Almoxarifado } \\
\text { Intermediário }\end{array}$} & \multicolumn{1}{c|}{$\begin{array}{c}\text { Posto Avançado da } \\
\text { FACE }\end{array}$} & $\begin{array}{c}\text { Posto Avançado do } \\
\text { IH }\end{array}$ \\
\hline $\begin{array}{l}\text { Não foi realizado. } \\
\text { Baseia-se no consumo } \\
\text { anterior. }\end{array}$ & $\begin{array}{l}\text { Não é realizado um É levantada conforme a } \\
\text { levantamento de das } \\
\text { necessidades dos postos } \\
\text { avançados. Feito com base } \\
\text { no histórico. }\end{array}$ & $\begin{array}{l}\text { Estimativa de consumo previsão de } \\
\text { feita pelo chefe }\end{array}$ & $\begin{array}{l}\text { consumo para a semana } \\
\end{array}$ \\
\hline
\end{tabular}

Análise do levantamento das necessidades: não é realizado, por nenhuma das unidades, um planejamento das necessidades de materiais. Existe apenas uma previsão da demanda referente ao que foi consumido em períodos anteriores ou através de julgamentos pessoais, sem nenhum estudo formal.

4.2.5 Pergunta: ajuste de estoque em função da variação de consumo.

- Foi apresentada a seguinte pergunta aos entrevistados: quais os meios utilizados para ajuste do estoque em função da variação de consumo? 
Quadro 5 - variação de consumo.

\begin{tabular}{|l|l|l|lr|}
\hline Almoxarifado Central & \multicolumn{1}{|c|}{$\begin{array}{c}\text { Almoxarifado } \\
\text { Intermediário }\end{array}$} & $\begin{array}{l}\text { Posto Avançado da } \\
\text { FACE }\end{array}$ & Posto Avançado do IH \\
\hline $\begin{array}{l}\text { Realiza apenas um } \\
\text { acréscimo de 15\% com } \\
\text { relação ao consumo } \\
\text { anterior. }\end{array}$ & $\begin{array}{l}\text { Não é realizada qualquer } \\
\text { ação. Os pedidos continuam } \\
\text { da mesma forma. }\end{array}$ & $\begin{array}{l}\text { O critério de } \\
\text { solicitação continua o } \\
\text { mesmo. }\end{array}$ & $\begin{array}{l}\text { Não são realizados } \\
\text { ajustes. O critério de } \\
\text { solicitação continua o } \\
\text { mesmo. }\end{array}$ \\
\hline
\end{tabular}

Análise da variação de consumo: o almoxarifado intermediário e os postos avançados não realizam ajustes em função da variação de consumo. Os critérios para os pedidos continuam da mesma forma, o que pode ocasionar na ruptura do estoque. Apenas o almoxarifado Central tem uma política de acrescentar no pedido $15 \%$ (quinze) sobre o consumo anterior, com o objetivo de prevenir as variações.

4.2.6 Pergunta: tempo de estocagem.

- Foi apresentada a seguinte pergunta aos entrevistados: qual o tempo médio de estocagem dos materiais dos tipos (A, B e C)?

Quadro 6 - Tempo de estocagem.

\begin{tabular}{|c|c|c|c|}
\hline Almoxarifado Central & $\begin{array}{l}\text { Almoxarifado } \\
\text { Intermediário }\end{array}$ & $\begin{array}{c}\text { Posto Avançado da } \\
\text { FACE }\end{array}$ & Posto Avançado do IH \\
\hline $\begin{array}{l}\text { O sistema não realiza } \\
\text { esse controle. Há } \\
\text { apenas um controle } \\
\text { manual sob a validade } \\
\text { dos produtos }\end{array}$ & $\begin{array}{l}\text { Não é determinado um } \\
\text { tempo médio de } \\
\text { estocagem para os tipos } \\
\text { de materiais. }\end{array}$ & $\begin{array}{l}\text { Não há tempo médio } \\
\text { de estocagem } \\
\text { definido para tipos de } \\
\text { materiais. }\end{array}$ & $\begin{array}{l}\text { Não há tempo médio } \\
\text { definido por categoria. São } \\
\text { todos armazenados por } \\
\text { uma semana. (tempo de } \\
\text { consumo }\end{array}$ \\
\hline
\end{tabular}

Análise do tempo de estocagem: nenhuma das unidades realiza o controle relativo ao tempo médio de estocagem dos materiais. Existe apenas um controle manual sob a validade dos produtos por parte do almoxarifado Central. No entanto há casos de produtos recebidos pelo almoxarifado intermediário que estão vencidos.

\section{3 - Variável "Itens em estoque".}

Gerir de forma eficiente os materiais em estoque é fundamental para manutenção da organização de um almoxarifado. As políticas de estoque, definidas por Viana (2002) como o conjunto de atos diretivos que estabelecem os princípios, diretrizes e normas de gerenciamento, devem ter como objetivo o pleno atendimento das necessidades institucionais. E buscando identificar qual a política de gestão para os itens estocados a variável em estudo 
vem com o propósito de analisar quais as formas de tratamento, a orientação para acomodação, classificação e a destinação do material considerado inútil.

\subsubsection{Pergunta: classificação e codificação dos itens}

- Foi apresentada a seguinte pergunta aos entrevistados: como e quem classifica, especifica e codifica o item estocado?

Quadro 1 - Classificação dos itens.

\begin{tabular}{|l|l|l|l|}
\hline Almoxarifado Central & \multicolumn{1}{|c|}{$\begin{array}{c}\text { Almoxarifado } \\
\text { Intermediário }\end{array}$} & $\begin{array}{c}\text { Posto Avançado da } \\
\text { FACE }\end{array}$ & Posto Avançado do IH \\
\hline $\begin{array}{l}\text { O sistema emite um } \\
\text { código alfanumérico } \\
\text { conforme especificação } \\
\text { do item }\end{array}$ & $\begin{array}{l}\text { Não há classificação e } \\
\text { nem codificação. }\end{array}$ & $\begin{array}{l}\text { Não há classificação e } \\
\text { nem codificação. }\end{array}$ & $\begin{array}{l}\text { Não há classificação e ou } \\
\text { codificação. }\end{array}$ \\
\hline
\end{tabular}

Análise da classificação e codificação dos itens: os materiais de um modo geral, na prática, não são classificados conforme uma metodologia definida, como por exemplo, a curva $\mathrm{ABC}$ ou curva de Pareto. Apenas o almoxarifado central realiza uma especificação padronizada de acordo com as características físicas e uma codificação alfanumérica. As demais unidades apenas organizam a armazenagem de acordo com o tipo/gênero.

\subsubsection{Pergunta: orientação para acomodação do material}

- Foi apresentada a seguinte pergunta aos entrevistados: qual a orientação existente para a acomodação do material?

Quadro 2 - Acomodação do material.

\begin{tabular}{|l|l|l|l|}
\hline Almoxarifado Central & \multicolumn{1}{|c|}{$\begin{array}{c}\text { Almoxarifado } \\
\text { Intermediário }\end{array}$} & $\begin{array}{c}\text { Posto Avançado da } \\
\text { FACE }\end{array}$ & Posto Avançado do IH \\
\hline $\begin{array}{l}\text { São acomodados de } \\
\text { forma separada } \\
\text { conforme o gênero/tipo }\end{array}$ & $\begin{array}{l}\text { Cada categoria (limpeza, } \\
\text { perecíveis, } \\
\text { higiênico) escritório, em armários } \\
\text { diferentes. }\end{array}$ & $\begin{array}{l}\text { São organizados em } \\
\text { um armário, por } \\
\text { categoria. }\end{array}$ & $\begin{array}{l}\text { Separados por tipo em } \\
\text { um armário. }\end{array}$ \\
\hline
\end{tabular}

Análise da orientação para acomodação do material: verificou-se que todas as unidades acomodam os materiais de acordo com a categoria, mas nessa época, de início de ano, o espaço no almoxarifado central está insuficiente devido o recebimento de grandes quantidades de materiais e bens. Dessa forma, a acomodação está totalmente prejudicada e fora dos padrões recomendados. 
4.3.3 Pergunta: variação da quantidade estocada.

- Foi apresentada a seguinte pergunta aos entrevistados: como é identificada a variação da quantidade estocada para meses do ano?

Quadro 3 - Variação de estoque.

\begin{tabular}{|l|l|l|l|}
\hline Almoxarifado Central & \multicolumn{1}{|c|}{$\begin{array}{c}\text { Almoxarifado } \\
\text { Intermediário }\end{array}$} & $\begin{array}{l}\text { Posto Avançado da } \\
\text { FACE }\end{array}$ & Posto Avançado do IH \\
\hline $\begin{array}{l}\text { Ocorre em épocas } \\
\text { sazonais (início e final } \\
\text { de ano) }\end{array}$ & $\begin{array}{l}\text { Final de ano a quantidade } \\
\text { estocada aumenta. }\end{array}$ & $\begin{array}{l}\text { Varia conforme } \\
\text { calendário acadêmico }\end{array}$ & $\begin{array}{l}\text { Início e término dos } \\
\text { semestres. }\end{array}$ \\
\hline
\end{tabular}

Análise da variação da quantidade estocada: basicamente, a variação de estoque está ligada ao calendário acadêmico. No final de ano a quantidade estocada diminui apenas para o almoxarifado central, pois o cronograma financeiro é fechado e não se permite mais realizar compras. E para as demais unidades a quantidade aumenta nesse período, pois as solicitações continuam da mesma forma apesar do consumo ser menor.

4.3.4 Pergunta: materiais ou tipos de bens estocados.

- Foi apresentada a seguinte pergunta aos entrevistados: quais os materiais ou tipos de bens são estocados/geridos?

Quadro 4 - materiais estocados.

\begin{tabular}{|c|c|c|c|}
\hline Almoxarifado Central & $\begin{array}{l}\text { Almoxarifado } \\
\text { Intermediário }\end{array}$ & $\begin{array}{c}\text { Posto Avançado da } \\
\text { FACE }\end{array}$ & Posto Avançado do IH \\
\hline $\begin{array}{l}\text { Limpeza, higiênicos, } \\
\text { perecíveis (açúcar, café } \\
\text { e água) os bens } \\
\text { patrimoniais e de } \\
\text { escritório. }\end{array}$ & $\begin{array}{l}\text { Materiais de escritório, } \\
\text { perecíveis (açúcar, café, } \\
\text { água) e os equipamentos } \\
\text { patrimoniais inservíveis. }\end{array}$ & $\begin{array}{l}\text { Apenas materiais de } \\
\text { escritório, nada do } \\
\text { tipo perecível. }\end{array}$ & $\begin{array}{l}\text { Apenas de expediente, } \\
\text { nada de perecível. }\end{array}$ \\
\hline
\end{tabular}

Análise dos materiais ou tipos de bens estocados: os bens patrimoniais ficam armazenados no almoxarifado Central até o registro patrimonial e a entrega junto ao setor solicitante. Já o almoxarifado Intermediário também funciona como um depósito pelo fato de guardar bens e equipamentos inservíveis. Os postos armazenam apenas materiais de consumo não perecíveis.

4.3.5 Pergunta: diferenciadas formas de tratamento dos itens.

- Foi apresentada a seguinte pergunta aos entrevistados: como são identificadas as formas diferenciadas de tratamento dos itens estocados? 
Quadro 5 - Tratamento dos itens.

\begin{tabular}{|l|l|l|l|}
\hline \multicolumn{1}{|c|}{ Almoxarifado Central } & \multicolumn{1}{|c|}{$\begin{array}{c}\text { Almoxarifado } \\
\text { Intermediário }\end{array}$} & $\begin{array}{c}\text { Posto Avançado da } \\
\text { FACE }\end{array}$ & Posto Avançado do IH \\
\hline $\begin{array}{l}\text { Os de laboratório em } \\
\text { congeladores e os de } \\
\text { maior consumo e mais } \\
\text { pesados ficam próximos } \\
\text { da saída. }\end{array}$ & $\begin{array}{l}\text { Uma parte dos copos, } \\
\text { papel higiênico e de } \\
\text { impressão ficam sobre um } \\
\text { balcão de forma mais } \\
\text { acessível. }\end{array}$ & $\begin{array}{l}\text { São estocados com a } \\
\text { mesma importância. }\end{array}$ & $\begin{array}{l}\text { Não há diferenciação } \\
\text { entre os itens estocados. }\end{array}$ \\
\end{tabular}

Análise das formas diferenciadas de tratamento: o almoxarifado Central e o intermediário possuem um tratamento diferenciado para os materiais de maior consumo, armazenando-os de uma maneira mais acessível e mais próxima da saída. Existe também uma armazenagem especial no almoxarifado Central para materiais de laboratório que necessitam de um ambiente climatizado, como freezers e refrigeradores. Já os postos avançados não possuem diferenciação no tratamento dos itens.

4.3.6 Pergunta: materiais ou tipos de bens estocados.

- Foi apresentada a seguinte pergunta aos entrevistados: qual a destinação do material inútil?

Quadro 6 - Material inútil.

\begin{tabular}{|l|l|l|l|}
\hline Almoxarifado Central & \multicolumn{1}{|c|}{$\begin{array}{c}\text { Almoxarifado } \\
\text { Intermediário }\end{array}$} & \multicolumn{1}{c|}{$\begin{array}{c}\text { Posto Avançado da } \\
\text { FACE }\end{array}$} & Posto Avançado do IH \\
\hline $\begin{array}{l}\text { São indicados para } \\
\text { descarte, leilão ou com } \\
\text { defeitos encaminhados descartados ou } \\
\text { para substituição. }\end{array}$ & $\begin{array}{l}\text { São descartados. } \\
\text { retornam para o } \\
\text { almoxarifado central. }\end{array}$ & $\begin{array}{l}\text { São } \\
\text { Apenas o tonner vazio } \\
\text { retorna para o } \\
\text { almoxarifado. }\end{array}$ & $\begin{array}{l}\text { Somente o tonner vazio } \\
\text { retorna para } \\
\text { almoxarifado } \\
\text { intermediário. }\end{array}$ \\
\hline
\end{tabular}

Análise da destinação dos materiais inúteis: apenas o almoxarifado Central segue um critério/padrão normativo com relação à destinação do material inútil, indicando ao setor de compras o descarte, leilão ou substituição, conforme o caso. As demais unidades realizam o próprio descarte do que não é mais útil e encaminham apenas o tonner e o garrafão de água, vazios, ou os materiais com defeitos para o seu respectivo fornecedor nessa cadeia.

\section{4 - Variável "Ambiente de armazenagem”.}

A armazenagem é uma atividade importante que tem por função ajudar no alcance dos objetivos da organização de forma a manter o suprimento adequado e necessário às atividades. De tal forma, analisar como se encontram os espaços de estocagem, a utilização de 
sua capacidade volumétrica, as adaptações necessárias e os equipamentos utilizados inseremse na sua gestão e vêm ao encontro da proposta de estudo dessa variável.

Segue abaixo apresentação visual dos ambientes de armazenagem em estudo: almoxarifado Central, Intermediário e de Ponta (postos avançados).

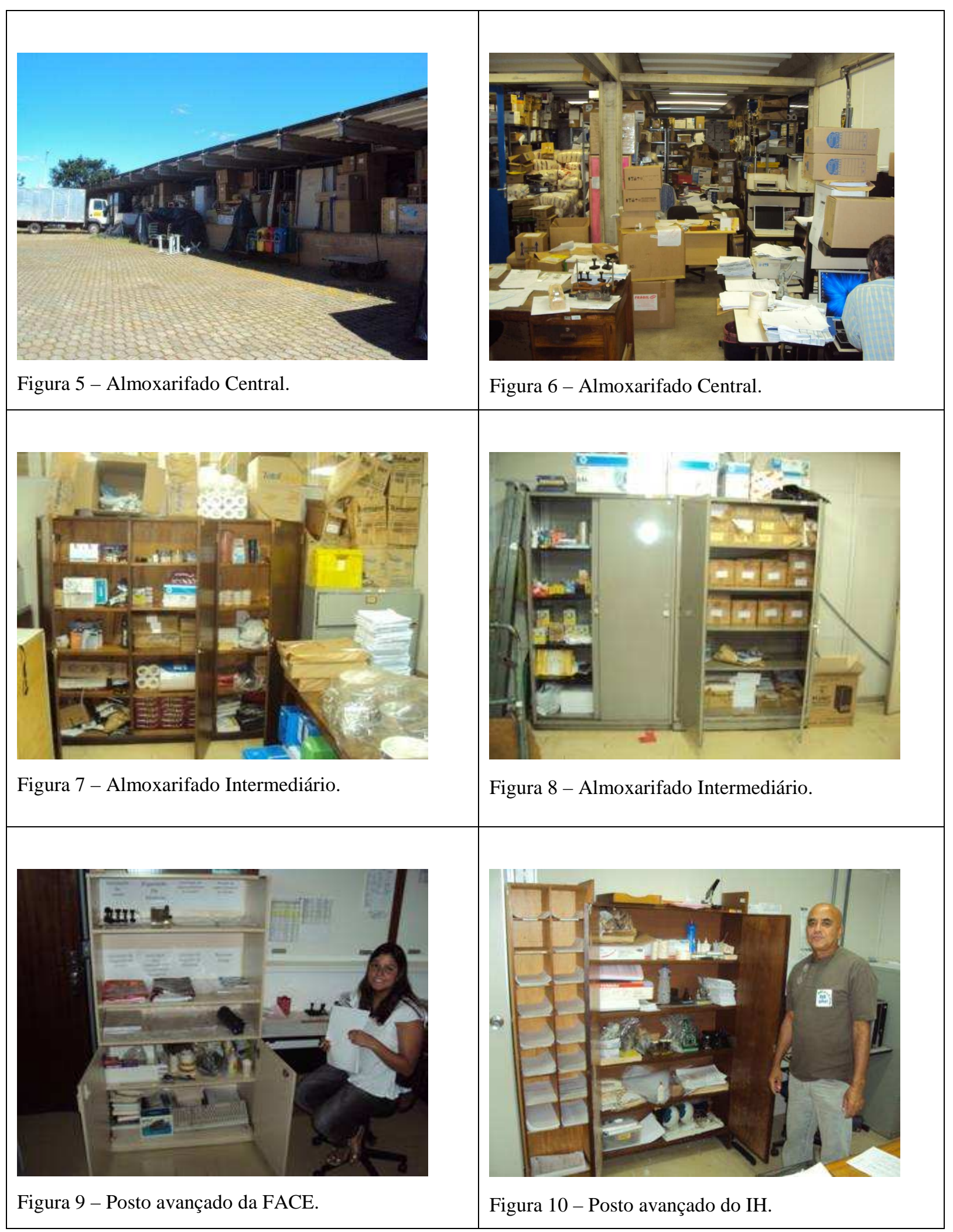


4.4.1 Pergunta: espaços de armazenagem.

- Foi apresentada a seguinte pergunta aos entrevistados: como se encontram os diversos espaços de armazenagem?

Quadro 1 - Espaço de armazenagem.

\begin{tabular}{|l|l|l|lr|}
\hline \multicolumn{1}{|c|}{$\begin{array}{c}\text { Almoxarifado } \\
\text { Central }\end{array}$} & \multicolumn{1}{|c|}{$\begin{array}{c}\text { Almoxarifado } \\
\text { Intermediário }\end{array}$} & \multicolumn{2}{c|}{ Posto Avançado da } & \multicolumn{2}{c|}{ Posto Avançado do IH } \\
\hline $\begin{array}{l}\text { Grande quantidade de } \\
\text { materiais e bens em } \\
\text { todos espaços } \\
\text { internos. }\end{array}$ & $\begin{array}{l}\text { É suficiente e também serve } \\
\text { como depósito de bens } \\
\text { inservíveis. }\end{array}$ & $\begin{array}{l}\text { Somente um armário } \\
\text { é utilizado para } \\
\text { armazenagem }\end{array}$ & $\begin{array}{l}\text { Apenas um armário é } \\
\text { utilizado } \\
\text { armazenagem }\end{array}$ & para \\
\hline
\end{tabular}

Análise do Espaço de armazenagem: o almoxarifado central apresenta um grande problema de insuficiência de espaço que pode ser sentida principalmente nas épocas de início de ano onde os bens e os materiais acabem acomodados de qualquer maneira e em todos os espaços disponíveis. O contrário acontece com o almoxarifado intermediário, onde o seu espaço é suficiente e a acomodação existente proporciona a formação de um depósito de bens inservíveis. Já os postos avançados não apresentam problema com espaço devido à pequena quantidade que é estocada.

4.4.2 Pergunta: adaptações das instalações físicas.

- Foi apresentada a seguinte pergunta aos entrevistados: quais as adaptações das instalações físicas apropriadas?

Quadro 2 - Adaptações das instalações físicas.

\begin{tabular}{|l|l|l|l|}
\hline \multicolumn{1}{|c|}{ Almoxarifado Central } & \multicolumn{1}{|c|}{$\begin{array}{c}\text { Almoxarifado } \\
\text { Intermediário }\end{array}$} & $\begin{array}{l}\text { Posto Avançado da } \\
\text { FACE }\end{array}$ & Posto Avançado do IH \\
\hline $\begin{array}{l}\text { Construída uma escada de } \\
\text { madeira. Um pequeno } \\
\text { anexo está } \\
\text { construído. }\end{array}$ & $\begin{array}{l}\text { Necessita de ventilação e } \\
\text { adaptação na porta de } \\
\text { acesso. }\end{array}$ & $\begin{array}{l}\text { Não há necessidade } \\
\text { de adaptações. }\end{array}$ & $\begin{array}{l}\text { Não há necessidade de } \\
\text { adaptações. }\end{array}$ \\
\hline
\end{tabular}

Análise das adaptações físicas: apenas uma escada de madeira foi construída para facilitar o acesso ao almoxarifado central. Como nenhuma modificação na instalação física do prédio pode ser executada um novo anexo está sendo construído para atender a questões de espaço. O almoxarifado intermediário também necessita de adaptações em seu espaço, mas, não há qualquer mobilização para tais. Já os postos avançados não necessitam de qualquer modificação nos aspectos relativos à armazenagem.

4.4.3 Pergunta: ocupação dos espaços horizontais e verticais. 
- Foi apresentada a seguinte pergunta aos entrevistados: como está a ocupação dos espaços horizontais e verticais?

Quadro 3 - Espaços horizontais e verticais.

\begin{tabular}{|l|l|l|l|}
\hline Almoxarifado Central & \multicolumn{1}{|c|}{$\begin{array}{c}\text { Almoxarifado } \\
\text { Intermediário }\end{array}$} & $\begin{array}{c}\text { Posto Avançado da } \\
\text { FACE }\end{array}$ & Posto Avançado do IH \\
\hline $\begin{array}{l}\text { O insuficiente espaço é } \\
\text { ocupado por estrados } \\
\text { de madeira e prateleiras } \\
\text { em aço. }\end{array}$ & $\begin{array}{l}\text { Apenas os espaços que } \\
\text { circundam as paredes são } \\
\text { aproveitados por prateleiras, } \\
\text { estantes e armários. }\end{array}$ & $\begin{array}{l}\text { Apenas a metade de } \\
\text { um armário de } \\
\text { madeira é utilizada. }\end{array}$ & $\begin{array}{l}\text { É utilizado apenas um } \\
\text { armário pequeno de } \\
\text { madeira. }\end{array}$ \\
\hline
\end{tabular}

Análise da ocupação dos espaços horizontais e verticais: Apenas o almoxarifado central apresenta problemas com a falta de espaço. As prateleiras e estrados são insuficientes para a quantidade de materiais. Todos os espaços disponíveis estão sendo ocupados, inclusive a salas de recebimento e de controle como também os corredores de acesso. Já no almoxarifado intermediário o espaço é suficiente, mas não é aproveitado da melhor forma, pois as prateleiras, estantes e armários ficam dispostos apenas ao redor das paredes ficando um "vão" central a ser ocupado por bens inservíveis. Para os postos apenas um armário é suficiente para a quantidade que é estocada.

4.4.4 Pergunta: equipamentos de armazenagem.

- Foi apresentada a seguinte pergunta aos entrevistados: quais os equipamentos de armazenagem (estantes, prateleiras, pallets, armários...) são utilizados?

Quadro 4 - Equipamentos de armazenagem.

\begin{tabular}{|l|l|l|l|}
\hline Almoxarifado Central & Almoxarifado Intermediário & $\begin{array}{l}\text { Posto Avançado da } \\
\text { FACE }\end{array}$ & \multicolumn{1}{|c|}{$\begin{array}{c}\text { Posto Avançado do } \\
\text { IH }\end{array}$} \\
\hline $\begin{array}{l}\text { São utilizadas } \\
\text { prateleiras em aço, } \\
\text { estrados de madeira, } \\
\text { geladeiras e freezers. }\end{array}$ & $\begin{array}{l}\text { Armário de aço com portas, } \\
\text { armários madeira e prateleiras } \\
\text { de madeira. Existem também 3 } \\
\text { (três) pallets mas sem } \\
\text { utilização. }\end{array}$ & $\begin{array}{l}\text { Apenas a metade de } \\
\text { um armário de } \\
\text { made é utilizada. }\end{array}$ & $\begin{array}{l}\text { É utilizado apenas um } \\
\text { armário pequeno de } \\
\text { madeira. }\end{array}$ \\
\hline
\end{tabular}

Análise dos equipamentos de armazenagem: apenas os equipamentos de armazenagem utilizados pelo almoxarifado intermediário não estão adequados para proporcionar um rápido acesso aos materiais, pois os armários de aço e madeira são todos trancados à chave. Quanto ao almoxarifado central os equipamentos são apenas insuficientes devido à falta de espaço. 
- Foi apresentada a seguinte pergunta aos entrevistados: quais as melhorias adequadas para armazenagem?

Quadro 5 - Melhorias para armazenagem.

\begin{tabular}{|l|l|l|l|}
\hline Almoxarifado Central & Almoxarifado Intermediário & $\begin{array}{c}\text { Posto Avançado da } \\
\text { FACE }\end{array}$ & $\begin{array}{c}\text { Posto Avançado do } \\
\text { IH }\end{array}$ \\
\hline $\begin{array}{l}\text { Construção de um novo } \\
\text { prédio dentro do padrão } \\
\text { recomendável para um } \\
\text { almoxarifado. }\end{array}$ & $\begin{array}{l}\text { Aumentar o tamanho da porta } \\
\text { de acesso, melhorar a a } \\
\text { circulação de ar, retirar os } \\
\text { bens e necessidade. } \\
\text { inservíveis. }\end{array}$ & $\begin{array}{l}\text { Para armazenagem } \\
\text { não há necessidade } \\
\text { de melhorias. }\end{array}$ \\
\end{tabular}

Análise das melhorias para armazenagem: apenas o almoxarifado Central necessita de um novo espaço físico, pois o atual não possui espaço suficiente e nem um padrão recomendável. Já as melhorias indicadas pelo o almoxarifado intermediário são de fácil resolução, porém nenhuma ação está sendo tomada para o alcance. Para os postos não há necessidade de melhorias devido à pequena quantidade de material que é estocada.

\section{5 - Variável "Transporte"}

O transporte por ser responsável pela política de execução da movimentação e distribuição de material representa para diversas empresas o elemento mais importante e mais visível em termos de valor e custos, pois são proporcionais ao tempo e a distancia de entrega. Portanto o estudo dessa variável tem por objetivo identificar os equipamentos e os meios de transportes utilizados para as entregas dos materiais pelas unidades em estudo, bem como as rotas e o tempo de distribuição.

4.5.1 Pergunta: meios de transporte utilizado.

- Foi apresentada a seguinte pergunta aos entrevistados: quais os meios de transporte utilizados para atender as solicitações?

Quadro 1 - Meios de transporte.

\begin{tabular}{|c|c|c|c|}
\hline Almoxarifado Central & $\begin{array}{l}\text { Almoxarifado } \\
\text { Intermediário }\end{array}$ & Posto Avançado da FACE & Posto Avançado do IH \\
\hline $\begin{array}{l}\text { Apenas um caminhão } \\
\text { tipo Baú é utilizado, e } \\
\text { atende bem a demanda }\end{array}$ & $\begin{array}{l}\text { Automóvel Fiat } \\
\text { uno Mille. }\end{array}$ & $\begin{array}{l}\text { Fica a cargo do } \\
\text { Almoxarifado intermediário. } \\
\text { Apenas recebe material. }\end{array}$ & $\begin{array}{l}\text { Fica a cargo do } \\
\text { Almoxarifado intermediário. } \\
\text { Apenas recebe material. }\end{array}$ \\
\hline
\end{tabular}


Análise dos meios de transporte: o transporte automotivo é utilizado apenas pelo almoxarifado central e o intermediário, pois os postos avançados são unidades que apenas recebem material para seu próprio consumo. Ressalta-se que a frota utilizada é própria da instituição.

4.5.2 Pergunta: equipamentos para movimentação interna.

- Foi apresentada a seguinte pergunta aos entrevistados: quais os equipamentos utilizados para movimentar os materiais internamente?

Quadro 2 - Equipamentos para movimentação interna.

\begin{tabular}{|l|l|l|l|}
\hline Almoxarifado Central & \multicolumn{1}{|c|}{$\begin{array}{c}\text { Almoxarifado } \\
\text { Intermediário }\end{array}$} & \multicolumn{1}{|c|}{$\begin{array}{c}\text { Posto Avançado da } \\
\text { FACE }\end{array}$} & Posto Avançado do IH \\
\hline $\begin{array}{l}\text { Carrinhos de duas e } \\
\text { quatro rodas e um } \\
\text { chamado de "burrinha"- } \\
\text { carga de 1 tonelada. }\end{array}$ & $\begin{array}{l}\text { É utilizado apenas um } \\
\text { carrinho pequeno e este } \\
\text { é suficiente. }\end{array}$ & $\begin{array}{l}\text { Não há necessidade de } \\
\text { equipamentos, pois o } \\
\text { estoque é pequeno. }\end{array}$ & $\begin{array}{l}\text { Não há necessidade de } \\
\text { equipamentos, pois o } \\
\text { estoque é pequeno. }\end{array}$ \\
\hline
\end{tabular}

Análise dos equipamentos para movimentação interna: os equipamentos utilizados pelo almoxarifado central e intermediário são suficientes e de acordo com o layout apresentado. Já os postos avançados não apresentam necessidade de equipamentos para movimentação devido à pequena quantidade que é armazenada.

4.5.3 Pergunta: rotas diárias/semanais para a distribuição.

- Foi apresentada a seguinte pergunta aos entrevistados: como são definidas as rotas diárias/semanais para a distribuição?

Quadro 3 - Rotas diárias/semanais.

\begin{tabular}{|c|c|c|c|}
\hline Almoxarifado Central & $\begin{array}{l}\text { Almoxarifado } \\
\text { Intermediário }\end{array}$ & $\begin{array}{c}\text { Posto Avançado da } \\
\text { FACE }\end{array}$ & Posto Avançado do IH \\
\hline $\begin{array}{l}\text { As rotas são diárias, } \\
\text { cada dia um ponto } \\
\text { diferente do campus é } \\
\text { atendido. }\end{array}$ & $\begin{array}{l}\text { Todas as manhãs o } \\
\text { motorista faz a entrega } \\
\text { das solicitações. }\end{array}$ & $\begin{array}{lrr}\text { Trata-se de setor } & \text { de } \\
\text { consumo. Recebem } & \text { os } \\
\text { materiais no mesmo dia } \\
\text { ou no dia seguinte. }\end{array}$ & $\begin{array}{l}\text { Trata-se de setor de } \\
\text { consumo. Recebem os } \\
\text { materiais no mesmo dia. }\end{array}$ \\
\hline
\end{tabular}

Análise das rotas diárias/semanais: a distribuição dos materiais do almoxarifado central segue um roteiro definido onde cada unidade tem seu pedido atendido pelo menos uma vez por semana. No entanto nessa época (janeiro a março) as rotas não estão sendo cumpridas corretamente devido a prioridade na entrega dos bens e equipamentos. As rotas de entregas do almoxarifado intermediário são realizadas todas as manhãs pelo motorista, que sai para 
entregar os processos nos postos juntamente com os materiais que foram solicitados. Conforme os postos essa rota satisfaz bem as suas necessidades.

4.5.4 Pergunta: retorno de material.

- Foi apresentada a seguinte pergunta aos entrevistados: o veículo que envia o material retorna com o que?

Quadro 4 - Retorno de material.

\begin{tabular}{|l|l|l|l|}
\hline Almoxarifado Central & \multicolumn{1}{|c|}{$\begin{array}{c}\text { Almoxarifado } \\
\text { Intermediário }\end{array}$} & \multicolumn{1}{|c|}{$\begin{array}{c}\text { Posto Avançado da } \\
\text { FACE }\end{array}$} & Posto Avançado do IH \\
\hline $\begin{array}{l}\text { Retorna com toner e } \\
\text { garrafão de água vazio, } \\
\text { ou materiais com } \\
\text { defeito. }\end{array}$ & $\begin{array}{l}\text { Retorna com toner } \\
\text { vazio ou algum material } \\
\text { com defeito. }\end{array}$ & $\begin{array}{l}\text { Retorna com toner vazio e } \\
\text { com alguns materiais com } \\
\text { defeito. }\end{array}$ & Retorna com toner vazio. \\
\hline
\end{tabular}

Análise do material que é retornado: os materiais que retornam com mais frequência aos seus respectivos fornecedores são os toners e os garrafões de água vazios como também os materiais com defeito.

\subsection{Variável "Informação Logística"}

Os Sistemas de Informação são os sistemas ou práticas utilizadas pelas empresas para melhorar o seu desempenho incluindo ter um custo operacional adequado, processos logísticos eficientes e integração com fornecedores e usuários. As "informações" devem ser disponibilizadas aos interessados de modo a subsidiá-los, através de consultas e relatórios gerenciais, à tomada de decisão em tempo real e imediato. Dada essa importância, o estudo dessa variável vem com o objetivo obter dados sobre os sistemas de informações que são utilizados pela instituição, para quem eles são disponibilizados e como está a integração dele com outros setores.

4.6.1 Pergunta: sistemas de informação utilizados.

- Foi apresentada a seguinte pergunta aos entrevistados: quais os sistemas de informação que são utilizados? 
Quadro 1 - Sistema de informação utilizado.

\begin{tabular}{|l|l|l|l|l|l|}
\hline Almoxarifado Central & \multicolumn{1}{|c|}{$\begin{array}{c}\text { Almoxarifado } \\
\text { Intermediário }\end{array}$} & \multicolumn{2}{|c|}{ Posto Avançado da } & \multicolumn{2}{|c|}{ Posto Avançado do IH } \\
\hline $\begin{array}{l}\text { Os mais utilizados são o } \\
\begin{array}{l}\text { SIMAR (sistemas de } \\
\text { materiais) e o SIPAT } \\
\text { (sistema de patrimônio) }\end{array}\end{array}$ & $\begin{array}{l}\text { Utiliza o SIMAR - } \\
\text { sistema de materiais }\end{array}$ & $\begin{array}{l}\text { Não há sistemas de } \\
\text { informação ou de } \\
\text { controle }\end{array}$ & $\begin{array}{l}\text { Não há sistemas de } \\
\text { informações sobre os } \\
\text { pedidos }\end{array}$ \\
\hline
\end{tabular}

Análise do sistema de informação utilizado: o almoxarifado Central também utiliza o sistema de patrimônio (SIPAT) de forma a buscar concisão nas informações entre o SIMAR, pois além do registro dos equipamentos serem realizados em seu ambiente, essa unidade também é responsável pela essa distribuição. O almoxarifado intermediário se utiliza apenas do SIMAR e, ainda, somente para solicitação de materiais e verificação de sua existência, pois o sistema não permite a visualização das quantidades em estoque. Já os postos avançados não possuem sistemas que auxiliem na gestão dos recursos materiais.

4.6.2 Pergunta: Disponibilização dos dados.

- Foi apresentada a seguinte pergunta aos entrevistados: os dados são disponibilizados para quem?

Quadro 2 - Disponibilização dos dados.

\begin{tabular}{|c|c|c|c|}
\hline Almoxarifado Central & $\begin{array}{l}\text { Almoxarifado } \\
\text { Intermediário }\end{array}$ & $\begin{array}{l}\text { Posto Avançado da } \\
\text { FACE }\end{array}$ & ançado do IH \\
\hline $\begin{array}{lr}\text { Para todos } & \text { os } \\
\text { funcionários } & \text { que } \\
\text { possuam acesso ao } & \text { as } \\
\text { sistema, mas com } & \text { bloqueios e restrições }\end{array}$ & $\begin{array}{l}\text { Somente o chefe e o } \\
\text { administrador possuem } \\
\text { acesso ao sistema. }\end{array}$ & $\begin{array}{lr}\text { Não possui acesso } & \text { ao } \\
\text { sistema. Dados } & \text { são } \\
\text { obtidos junto } & \text { ao } \\
\text { almoxarifado } & \\
\text { intermediário. } & \end{array}$ & $\begin{array}{lr}\text { Não possui acesso ao } \\
\text { sistema. Dados são } \\
\text { obtidos junto } \\
\text { almoxarifado } \\
\text { intermediário. }\end{array}$ \\
\hline
\end{tabular}

Análise da disponibilização dos dados: os dados estão disponibilizados no sistema para os gestores de cada unidade, mas com alguns bloqueios. Pelo fato do sistema não disponibilizar todas as informações, a maioria delas são fornecidos ao solicitante por telefone.

4.6.3 Pergunta: integração entre o setor de compras e o de consumo.

- Foi apresentada a seguinte pergunta aos entrevistados: como está integrada a comunicação entre o setor de compras os setores de consumo? 
Quadro 3 - Integração compras/setor consumo.

\begin{tabular}{|l|l|l|l|}
\hline \multicolumn{1}{|c|}{ Almoxarifado Central } & \multicolumn{1}{|c|}{$\begin{array}{c}\text { Almoxarifado } \\
\text { Intermediário }\end{array}$} & \multicolumn{1}{|c|}{$\begin{array}{c}\text { Posto Avançado da } \\
\text { FACE }\end{array}$} & Posto Avançado do IH \\
\hline $\begin{array}{l}\text { Existe uma integração no } \\
\text { sistema, mas está } \\
\text { suspensa pelo CPD. }\end{array}$ & $\begin{array}{l}\text { O campo existente no } \\
\text { SIMAR não é } \\
\text { liberado a SAA. }\end{array}$ & $\begin{array}{l}\text { O posto avançado não tem } \\
\text { contato direto ou ou } \\
\text { integração com o setor de } \\
\text { compras }\end{array}$ & $\begin{array}{l}\text { Não há integração do } \\
\text { Posto com o setor de } \\
\text { compras da UnB }\end{array}$ \\
\hline
\end{tabular}

Análise da integração entre setor de compras e consumo: existe uma integração no sistema com o setor de compras, mas essa é pequena e está suspensa até que o centro de processamento de dados (CPD) finalize o processo de aperfeiçoamento. Por enquanto a comunicação com o setor de compras está sendo realizada por telefone. As informações sobre as compras solicitadas pelos postos também são obtidas junta à SAA, por telefone ou pessoalmente, pois não há contato direto com o setor de compras.

4.6.4 Pergunta: visualização do estoque virtual e físico.

- Foi apresentada a seguinte pergunta aos entrevistados: como é possível visualizar simultaneamente os estoques: virtual (pedido) e o físico (armazenado)?

Quadro 4 - Estoque virtual e físico.

\begin{tabular}{|c|c|c|c|}
\hline Almoxarifado Central & $\begin{array}{l}\text { Almoxarifado } \\
\text { Intermediário }\end{array}$ & $\begin{array}{c}\text { Posto Avançado da } \\
\text { FACE }\end{array}$ & Posto Avançado do IH \\
\hline $\begin{array}{l}\text { Não há visualização de } \\
\text { estoque virtual. } \\
\text { Existe apenas do que } \\
\text { está armazenado }\end{array}$ & $\begin{array}{l}\text { Não há controle ou } \\
\text { sistema interno da SAA } \\
\text { que permita tal } \\
\text { visualização. }\end{array}$ & $\begin{array}{l}\text { Não há sistema de } \\
\text { controle de estoque } \\
\text { acessível pelo posto }\end{array}$ & $\begin{array}{l}\text { O Posto não possui } \\
\text { qualquer sistema de } \\
\text { controle de estoque }\end{array}$ \\
\hline
\end{tabular}

Análise sobre a visualização do estoque virtual e físico: o sistema SIMAR não possibilita a visualização do estoque virtual, ou seja, dos pedidos que estejam em processamento e nem das quantidades exatas existentes no estoque do almoxarifado central. O sistema apenas demonstra se há ou não determinado material em estoque. No entanto há relatos de casos em que o sistema fornece a informação de existência, mas, na prática o mesmo está em falta no estoque. Os postos avançados não possuem acesso a qualquer sistema de gestão de recursos materiais, portanto as informações são obtidas por telefone ou pessoalmente.

\subsection{Variável "Pessoal"}

As tarefas de administrar um almoxarifado exigem muito mais que o simples manuseio dos materiais. E de acordo com suas proporções e complexidades exigem 
profissionais cada vez mais qualificados e com conhecimentos profundos na área. Diante disso, o estudo da "variável pessoal” vem buscar identificar os aspectos característicos com relação à qualificação, distribuição e segurança dos profissionais que atuam na área.

4.7.1 Pergunta: qualificação dos profissionais.

- Foi apresentada a seguinte pergunta aos entrevistados: como está a qualificação dos profissionais que atuam na área?

Quadro 1 - Qualificação dos profissionais.

\begin{tabular}{|c|c|c|c|}
\hline $\begin{array}{c}\text { Almoxarifado } \\
\text { Central }\end{array}$ & $\begin{array}{l}\text { Almoxarifado } \\
\text { Intermediário }\end{array}$ & $\begin{array}{l}\text { Posto Avançado da } \\
\text { FACE }\end{array}$ & Posto Avançado do IH \\
\hline $\begin{array}{l}\text { O chefe possui nível } \\
\text { superior e os demais } \\
\text { apenas nível médio }\end{array}$ & $\begin{array}{lr}\text { Dois servidores efetivos, } \\
\text { formados } & \text { em } \\
\text { administração e } & \text { dois } \\
\text { contratados de } & \text { nível } \\
\text { médio. } & \end{array}$ & \begin{tabular}{llr}
\multicolumn{3}{l}{ A supervisora é graduada } \\
em letras e & os & dois \\
contratados & & são \\
graduados & & em \\
administração. & &
\end{tabular} & $\begin{array}{l}\text { A supervisora cursa } \\
\text { graduação em processos } \\
\text { gerenciais e a outra é } \\
\text { contratada formada em } \\
\text { administração }\end{array}$ \\
\hline
\end{tabular}

Análise da qualificação dos profissionais: os supervisores de cada unidade possuem ou estão cursando um nível superior, e em sua maioria na área de administração. Os assistentes e auxiliares do almoxarifado Central e Intermediário não possuem qualquer graduação, diferentemente dos que atuam nos postos avançados.

4.7.2 Pergunta: equipamentos disponíveis para proteção.

- Foi apresentada a seguinte pergunta aos entrevistados: quais equipamentos que estão disponíveis para proteção dos envolvidos?

Quadro 2 - Equipamentos para proteção.

\begin{tabular}{|l|l|l|l|}
\hline Almoxarifado Central & \multicolumn{1}{|c|}{$\begin{array}{c}\text { Almoxarifado } \\
\text { Intermediário }\end{array}$} & \multicolumn{1}{c|}{$\begin{array}{c}\text { Posto Avançado da } \\
\text { FACE }\end{array}$} & Posto Avançado do IH \\
\hline $\begin{array}{l}\text { Não é fornecido para } \\
\text { proteção individual. } \\
\begin{array}{l}\text { Existem há equipamentos } \\
\text { extintores e hidrantes }\end{array}\end{array}$ & $\begin{array}{l}\text { Não existe qualquer } \\
\text { individuais. Há somente } \\
\text { um extintor. }\end{array}$ & $\begin{array}{l}\text { Não } \\
\text { equipamento de proteção } \\
\text { ou de combate. }\end{array}$ & $\begin{array}{l}\text { Não } \\
\text { equipamentos. }\end{array}$ \\
\hline
\end{tabular}

Análise dos equipamentos de proteção: não é fornecido qualquer equipamento de proteção individual para os funcionários do almoxarifado Central e Intermediário. Existem apenas extintores e mangueiras de incêndio. Já os postos avançados não possuem equipamentos de proteção e nem de combate a incêndios. 
4.7.3 - Pergunta: distribuição dos funcionários por setor.

- Foi apresentada a seguinte pergunta aos entrevistados: como está a distribuição dos funcionários para cada setor interno?

Quadro 3 - Distribuição dos funcionários.

\begin{tabular}{|l|l|l|l|}
\hline \multicolumn{1}{|c|}{ Almoxarifado Central } & \multicolumn{1}{|c|}{$\begin{array}{c}\text { Almoxarifado } \\
\text { Intermediário }\end{array}$} & \multicolumn{1}{|c|}{$\begin{array}{c}\text { Posto Avançado da } \\
\text { FACE }\end{array}$} & $\begin{array}{c}\text { Posto Avançado do } \\
\text { IH }\end{array}$ \\
\hline $\begin{array}{l}\text { O Setor de triagem } e \\
\text { distribuição: } \text { chefe e } \\
\text { auxiliares. } \text { Recepção/ } \\
\text { controle: } \text { Ass. }\end{array}$ & $\begin{array}{l}\text { Os dois servidores } \\
\text { respondem pelas } \\
\text { solicitações e controle e os } \\
\text { Administrativo e mais }\end{array}$ & $\begin{array}{l}\text { Qualquer funcionário } \\
\text { solicita e armazena o } \\
\text { material. }\end{array}$ & $\begin{array}{l}\text { Não possui divisão de } \\
\text { atividades. }\end{array}$ \\
auxiliares. & armazenagem e entrega. & & \\
\end{tabular}

Análise da distribuição dos funcionários por setor: Apenas o almoxarifado Central possui setores internos dentro da sua estrutura física, sendo um o setor de triagem e distribuição e o outro o de recepção e controle dos materiais. No almoxarifado intermediário ocorre apenas a divisão das atividades, diferentemente dos postos, onde qualquer envolvido realiza qualquer atividade.

\subsection{4 - Pergunta: treinamento e capacitação.}

- Foi apresentada a seguinte pergunta aos entrevistados: existe treinamento/ capacitação periódica dos funcionários com qual periodicidade?

Quadro 4 - Treinamento/capacitação.

\begin{tabular}{|l|l|l|l|}
\hline \multicolumn{1}{|c|}{ Almoxarifado Central } & \multicolumn{1}{|c|}{$\begin{array}{c}\text { Almoxarifado } \\
\text { Intermediário }\end{array}$} & $\begin{array}{c}\text { Posto Avançado da } \\
\text { FACE }\end{array}$ & Posto Avançado do IH \\
\hline $\begin{array}{l}\text { Não há treinamento ou } \\
\text { capacitação, as̃o há e nem houve } \\
\text { informações sã } \\
\text { passadas no dia-dia com } \\
\text { a prática. }\end{array}$ & $\begin{array}{l}\text { Nãoa de administração } \\
\text { cursos de capacitação } \\
\text { ou treinamento. }\end{array}$ & $\begin{array}{l}\text { Na área de administração } \\
\text { de materiais nunca houve } \\
\text { capacitação }\end{array}$ & $\begin{array}{l}\text { Na área materiais nunca houve } \\
\text { de } \\
\text { capacitação }\end{array}$ \\
\hline
\end{tabular}

Análise do treinamento/capacitação dos funcionários: de um modo geral não há e nem houve qualquer treinamento ou capacitação de modo a auxiliar no desenvolvimento das atividades. Existe um consenso de que todos os envolvidos, inclusive os chefes, necessitam de cursos que atualizem os conhecimentos e melhore o desempenho. 


\section{Conclusões e Recomendações}

A logística de Armazenagem Intermediária exerce um importante papel de suprir as lacunas existentes no processo logístico institucional. Por guardar certas quantidades de recursos materiais em seu estoque, essa unidade proporciona um rápido atendimento tanto às suas necessidades quanto às das suas subunidades, neste caso os postos avançados. Tais postos de atendimento, por serem de pequena estrutura física com uma composição que varia de 2 (dois) a 4 (quatro) funcionários e por acondicionarem pequenas quantidades de materiais, além de geralmente afastados, não necessitam e não possuem contato direto com o almoxarifado central. Dependem exclusivamente da logística de armazenagem intermediária, situada na SAA, que favorece, com um eficiente fornecimento, a não interrupção de suas atividades devido a eventuais falhas de fornecimento que possam ocorrer por parte da central.

De acordo com o que foi estabelecido na parte introdutória, este estudo teve como objetivo analisar a gestão de recursos materiais na administração pública, de modo a avaliar a importância que a logística de armazenagem intermediária de uma unidade possui para com suas subunidades e como poderia ser sua forma de gestão dentro dessa cadeia de logística interna. De uma maneira mais específica buscou-se compreender aspectos relativos ao tempo efetivo do pedido, ambientes de armazenagem, o fluxo da cadeia logística interna e os problemas ocorrentes durante o exercício.

Para atingir esse objetivo foi desenvolvido um referencial teórico e, como síntese desse referencial e também com base nos pontos específicos, definiu-se as variáveis que nortearam as análises e discussões dos dados durante o desenvolvimento desse estudo.

\subsection{Conclusão sobre as variáveis}

A definição das variáveis propostas constituiu-se como base fundamental para obtenção das informações necessárias. Elas vieram com o objetivo de auxiliar na compreensão da relação entre as causas e efeitos e proporcionar explicações para certos fatos provenientes da gestão dos recursos materiais. Desenvolveu-se, a partir de então, uma discussão das práticas logísticas e de gestão dos estoques de materiais na administração pública, para identificação dos impactos de uma logística de armazenagem intermediária, tomando como base o estudo das variáveis como se segue. 


\subsubsection{Variável "Pedido"}

Os aspectos logísticos do "pedido" necessitam de ajustes na condução e gerenciamento pelas unidades. Os pedidos realizados devem ser entregues em um período mais satisfatório e nas quantidades que foram solicitadas para que facilite na gestão e na formação de um eficiente estoque por parte do almoxarifado intermediário e conseqüentemente por parte dos postos avançados.

Ao analisar essa cadeia de logística interna verifica-se que, pela pequena quantidade de material solicitado e pelo seu porte, não é viável a armazenagem de ponta, ou seja, os postos avançados, realizarem seus pedidos de materiais diretamente ao almoxarifado Central. Além disso, por serem de difícil localização e acesso e não disporem do sistema necessário para tal, o tempo de entrega dos pedidos será maior do que o atual, o que tornará o lead time insatisfatório. Prova disso é o prazo relativo às entregas no almoxarifado intermediário que varia de 04 (quatro) dias para mais.

Portanto, quanto ao tempo de entrega, o fluxo dessa cadeia de logística interna, com a armazenagem intermediária, vem atendendo bem as necessidades de armazenagem dos postos. A maior dificuldade existente para estas unidades está relacionada apenas a não entrega de todas as quantidades de materiais solicitadas e a falta de informações logísticas.

Assim, os principais fatores e deficiências relativos ao fator pedido estão basicamente atrelados à ausência de um sistema de informação de qualidade. As informações logísticas são, portanto, consideradas elementos chave para a gestão eficaz do almoxarifado intermediário e dos postos. Estas devem estar disponíveis em tempo hábil e com consistência, de forma a melhorar a integração entre as partes envolvidas (Compras, Central, Intermediário e Postos), fornecendo, por exemplo, o status do pedido ao seu solicitante, algo do qual o sistema utilizado (SIMAR) necessita realizar.

\subsubsection{Variável "estocagem"}

O controle de estoque depende de um sistema eficiente cujo qual deve fornecer, a qualquer momento as quantidades que se encontram à disposição e onde estão localizadas. Portanto, as unidades em estudo, principalmente o almoxarifado intermediário, por ser fornecedor para os postos, necessitam de um sistema de gerenciamento que auxilie no controle e na projeção de níveis de estoque adequados de forma a garantir segurança e 
equilíbrio entre estoque e consumo. Tais níveis, apesar de determinados apenas pelo almoxarifado central, devem também, ser revistos e atualizados periodicamente a fim de evitar problemas provocados com variações de consumo.

De um modo geral a política de ressuprimento utilizada pelo almoxarifado intermediário precisa ser revista e aliada a um indispensável planejamento das necessidades de materiais, para que se favoreça a uma gestão de estoques não baseada em riscos, pois, da forma como vem ocorrendo, os postos avançados ficaram propensos à falta de materiais podendo se tornar incapazes de atender às necessidades dos clientes e/ou usuários.

\subsubsection{Variável "itens em estoque"}

Os aspectos de gerenciamento dos itens em estoque repercutem diretamente no atendimento final ao usuário. Dessa forma, as unidades precisam definir um método de classificação, como a do tipo $\mathrm{ABC}$ por exemplo, afim de que não haja um sério comprometimento no processo de seleção e decisão das prioridades, além de um ressuprimento em desacordo com as necessidades.

No entanto, os postos avançados, por acondicionarem quantidades pequenas de materiais, não necessitam de uma classificação ou codificação dos itens, como no caso do almoxarifado intermediário que possui uma estrutura maior e uma função de fornecedor para essas subunidades.

Apesar de um breve conhecimento sobre as épocas de ocorrência da variação da quantidade estocada, tanto o almoxarifado intermediário quanto os postos necessitam realizar um planejamento de estoque, de forma a manter um nível adequado capaz de atender com equilíbrio ao consumo sazonal.

Além disso, a acomodação dos materiais no almoxarifado intermediário precisa de cuidados em sua organização, pois os bens patrimoniais inservíveis deveriam ser encaminhados ao depósito central ao invés de armazenados no mesmo espaço físico que os materiais de consumo. Isso melhoraria o fluxo de entrada, a circulação interna e a saída dos produtos para os postos avançados.

Por parte do almoxarifado Central, essa acomodação deve ser realizada seguindo as especificações dos fabricantes e organizada para proporcionar uma movimentação eficiente, pois os materiais estão empilhados de qualquer maneira, de modo a danificar as embalagens e produtos, além de dificultar a circulação pelos corredores e a entrada e saída no almoxarifado. 
Os cuidados relativos a essa acomodação são importantes, pois as outras unidades integrantes dessa cadeia logística, almoxarifado intermediário e postos avançados, necessitarão da plena conservação e qualidade dos seus produtos até o seu consumo.

\subsubsection{Variável "ambiente de armazenagem"}

O objetivo principal do armazenamento, segundo Viana (2002) é utilizar o espaço nas três dimensões (comprimento, largura e altura) da forma mais eficiente possível. Sendo assim, a disposição dos equipamentos de armazenagem e a acomodação dos materiais no almoxarifado intermediário devem ser realizadas de maneira a não prejudicar a correta utilização do espaço, buscando sempre proporcionar uma movimentação rápida e fácil dos suprimentos.

É visível que a origem dos diversos problemas relativos à armazenagem é a falta de espaço, e algumas medidas já estão sendo tomadas em relação ao almoxarifado central, como a construção de um galpão de menor porte (já em andamento) que servirá como anexo, a fim de minimizar as questões de acomodação citadas anteriormente. Mas, além desse, o ideal é que se construa um novo prédio, dentro dos padrões recomendáveis, em substituição ao atual principal.

Já no ambiente do almoxarifado intermediário, foco desse estudo, a necessidade maior está basicamente ligada ao planejamento de um bom layout, pois o espaço é suficiente, apenas precisa ser aproveitado da melhor forma. Além de adaptações na porta de acesso e na ventilação, as prateleiras, estantes e os armários devem ser substituídos por outros mais indicados e dispostos de uma maneira a fazer desse almoxarifado um bom modelo de organização com operações mais eficientes.

\subsubsection{Variável "transporte"}

Por ser o custo um dos fatores mais preocupantes na política de transportes de qualquer empresa ou instituição, a escolha do caminhão "Baú", por parte do almoxarifado central, juntamente com o plano de rotas definido para efetuar as entregas, representam, na visão de Bowersox e Closs (2001) à chamada Economia de Escala. Essa é obtida quando a capacidade do veículo é utilizada de forma a comportar maior quantidade de pedidos durante a entrega. 
Apesar da redução de custos que é proporcionada, o serviço em si, como distribuir o produto certo no lugar certo, tem que ser o principal fator determinante na política de transportes de distribuição. É necessário, portanto, haver mais um automóvel a fim de evitar falhas nas entregas e diminuir o lead time entre o almoxarifado intermediário. Esse tempo de entrega é importantíssimo, pois qualquer atraso pode prejudicar o fluxo da cadeia até os postos avançados e implicar no atendimento ao usuário final.

Outro ponto que merece atenção é a redução de custos e a melhora na eficiência quanto à utilização dos meios de transporte no tratamento da logística reversa, onde o mesmo veículo que realiza a entrega nos postos avançados também efetua o recolhimento dos materiais inservíveis. Já em posse do almoxarifado intermediário tais materiais são repassados ao "Central" através do mesmo processo. Em seguida, são indicados ao setor de compras para que seja feita a substituição junto ao fornecedor, no caso de defeito, ou conduzidos para leilão caso não sejam mais de utilidade, de forma a proporcionar uma baixa no estoque e liberação de espaço físico. Existe ainda, o caso dos "retornáveis", como os garrafões de água vazios, que são recolhidos diretamente pelo fornecedor no almoxarifado Central no momento da entrega de fornecimento.

Todo esse processo, apesar de proporcionar redução nos custos e uma melhor eficiência, necessita apenas da aplicação de um formulário de devolução, contendo as justificativas/ motivos, de forma a identificar a origem da ocorrência e proporcionar um maior controle no fluxo desses itens.

\subsubsection{Variável "Informações logísticas"}

O sistema de materiais utilizado pela instituição em estudo deve ser ajustado de forma a proporcionar, aos profissionais que exercem as funções de gestão no almoxarifado intermediário, uma informação mais confiável e suficiente para um planejamento e controle efetivo da administração de materiais, como também uma melhor otimização da distribuição. São necessárias informações importantes como: a visualização da quantidade de determinado produto existente em estoque; o andamento das solicitações internas e o acompanhamento integrado dos pedidos externos junto ao setor de compras. Tudo isso facilitaria o processo de gestão, pois dessa forma se conseguiria manter um estoque adequado, reduziria certos tempos de ressuprimento e melhoraria a qualidade do atendimento junto aos postos. 


\subsubsection{Variável "Pessoal"}

Os profissionais envolvidos na gestão do almoxarifado intermediário possuem, em sua maioria, formação em nível superior numa área até condizente com a em estudo o que, de certa forma, facilita um pouco na administração dos recursos materiais. Mas para a execução das melhores práticas de gestão, como o exame, registro, liberação, controle de materiais, entre outros, algo a mais precisa ser observado pela instituição, que é um pessoal treinado, especializado e capacitado para exercer as diversas funções que essa atividade técnica exige.

Além disso, o fator pessoal também merece total atenção quando o assunto é segurança no trabalho. Os funcionários do almoxarifado Intermediário e também os do "Central”, locais de maior manuseio, necessitam de todo tipo de equipamento de proteção individual exigido para o bom andamento das atividades. E apesar de sua pequena estrutura, os postos avançados, mesmo não necessitando de equipamentos individuais, merecem atenção pelo menos com relação aos meios de combate a prováveis incêndios.

\subsection{Recomendações}

Ao concluir o trabalho, recomenda-se o aprofundamento do estudo na área de logística empresarial, com as seguintes características ou temas:

- Análise do impacto dos pedidos no processo produtivo;

- Viabilidade de se implementar um novo sistema de controle de materiais.

- Análise do impacto da logística reversa no processo produtivo. 


\section{Referências Bibliográficas}

ACEVEDO, Cláudia Rosa e NOHARA, Jouliana Jordan. Monografia no curso de Administração: Guia Completo de Conteúdo e Forma. $3^{\text {a }}$ Ed. Editora Atlas S.A, 2007.

ALBUQUERQUE, Eric Sarmanho de. Roteiro de Direito Administrativo. Brasília: Ed. Fortium, 2007.

ALVARENGA, Antonio Carlos e NOVAES, Antonio Galvão N. Logística Aplicada: Suprimento e Distribuição Física. $3^{\text {a }}$ Ed. - São Paulo. Editora Blucher, 2000.

ARAÚJO, Jorge Sequeira de. Administração de Materiais. $5^{\text {a }}$ Ed - São Paulo, Editora Atlas, 1985.

BALLOU, Ronald H. Gerenciamento da Cadeia de Suprimentos/logística empresarial, $5^{\mathrm{a}}$ ed. Bookman. 2006.

BALLOU, Ronald. H. Gerenciamento da cadeia de suprimentos: Planejamento, organização e logística empresarial. Porto Alegre: Bookman, 2001.

BOWERSOX, Donald J e CLOSS, David J. Logística Empresarial: O Processo de Integração da Cadeia de Suprimento. São Paulo: Editora Atlas S.A., 2001.

CURY, Antonio. Organização e Métodos: Uma visão Holística. 8 ed. São Paulo. Editora Atlas, 2005.

DIAS, Marco Aurélio P. Administração de Materiais: uma abordagem logística. $4^{\mathrm{a}}$ Ed. São Paulo. Editora Atlas, 2008.

MARTINS, Petrônio Garcia e ALT, Paulo Renato Campos. Administração de Materiais e Recursos Patrimoniais. $2^{a}$ Ed. São Paulo: Editora Saraiva 2006.

MELlO, Celso Antônio Bandeira. Curso de Direito Administrativo. $11^{\text {a }}$ Ed. São Paulo. Editora Malheiros, 2003.

POZO, H. Administração de Recursos Materiais e Patrimoniais. São Paulo: Atlas, 2002.

VECINA Neto, Gonzalo e REINHARDT Filho, Wilson. Gestão de Recursos Materiais e de Medicamentos- São Paulo. Série Saúde e Cidadania. 1998

VIANA, João José. Administração de Materiais: Um Enfoque Prático. São Paulo:

Editora Atlas, 2002.

SLACK, N. et al. Administração da Produção. Tradução de Maria Teresa Corrêa de Oliveira, Fábio Alher. Revisão técnica de Henrique Luiz Corrêa. 2. ed. São Paulo: Atlas, 2008. 


\title{
APÊNDICE
}

\author{
Roteiro da entrevista
}

\section{Universidade de Brasília - UnB}

FACE

\author{
PESQUISA DE CAMPO - LOGÍSTICA DE ARMAZENAGEM \\ Localização:（）Central ( ) Intermediária ( ) Ponta-Atendimento ao aluno.
}

Cargo: Setor:

\section{Variáveis de Pesquisa}

\section{Pedido}

- Qual o led time do pedido e é satisfatório (do momento da solicitação até a entrega)?

- Os pedidos são atendidos nas devidas quantidades? Qual o percentual atendido?

- Como é visualizado o controle/acompanhamento de cada pedido?

- Qual o critério para atender pedidos emergenciais?

- Quais são os motivos para devolução de um pedido?

\section{Estocagem}

- Como é realizado o controle físico (entrada e saída) dos materiais?

- Quais os níveis de controle de estoque existente para os materiais (estoque mínimo, máximo e de segurança)?

- Que parâmetro para o ressuprimento é utilizado?

- Como é levantada a necessidade de cada setor?

- Quais os meios utilizados para ajuste do estoque em função da variação de consumo?

- Qual o tempo médio de estocagem dos materiais dos tipos (A, B e C)?

\section{Itens estocados}

- Como e quem classifica, especifica e codifica o item estocado?

- Qual orientação existente para orientar a acomodação do material?

- Como é identificada a variação da quantidade estocada para meses do ano?

- Quais os materiais ou tipos de bens são estocados/geridos?

- Como são identificadas as formas diferenciadas de tratamento dos itens estocados?

- Qual a destinação do material inútil? 


\section{Ambiente de armazenagem}

- Como se encontram os diversos espaços de armazenagem?

- Quais as adaptações das instalações físicas apropriadas?

- Como está a ocupação dos espaços horizontais e verticais?

- Quais os equipamentos de armazenagem (estantes, prateleiras, pallets, armários...) são utilizados?

- Quais as melhorias adequadas para armazenagem?

\section{Transporte}

- Quais os meios de transporte utilizados para atender as solicitações?

- Quais os equipamentos utilizados para movimentar os materiais internamente?

- Como são definidas as rotas diárias/semanais para a distribuição?

- O veículo que envia o material retorna com o quê?

\section{Informação Logística}

- Quais os sistemas de informação que são utilizados?

- Os dados são disponibilizados para quem?

- Como está integrada a comunicação entre o setor de compras os setores de consumo?

- Como é possível visualizar simultaneamente os estoques: virtual (pedido) e o físico (armazenado)?

\section{Pessoal}

- Como está a qualificação dos profissionais que atuam na área?

- Quais equipamentos que estão disponíveis para proteção dos envolvidos?

- Como está a distribuição dos funcionários para cada setor interno?

- Existe treinamento/capacitação periódica dos funcionários com qual periodicidade?

Agradecemos a colaboração! 